\title{
Preharvest iodine sprays at high rates are more effective in biofortification of apples than soil application
}

\author{
Paweł Wójcik (D) Marzena Wójcik (D)
}

Received: 11 January 2021 / Accepted: 30 April 2021 / Published online: 3 June 2021

(C) The Author(s) 2021

\begin{abstract}
Aim Agronomic biofortification of fruit with iodine (I) has become an innovative approach in contemporary agriculture. In this study, we evaluated the influence of soil- and foliar I applications on absorption of this nutrient by apple (Malus domestica Borth.) trees, as well as on growth and yield responses of the plants.

Methods In 2018-2019, 'Red Jonaprince' apple trees, grown on sandy loam soil, were treated with potassium iodide (KI) or K-iodate $\left(\mathrm{KIO}_{3}\right)$ through soil application (at a rate of $4 \mathrm{~kg}, 8 \mathrm{~kg}$ or $12 \mathrm{~kg} \mathrm{I} \mathrm{ha}{ }^{-1}$ ) or preharvest sprays (at a rate of $0.5 \mathrm{~kg}, 1 \mathrm{~kg}$ or $1.5 \mathrm{~kg} \mathrm{I} \mathrm{ha}^{-1}$ ).

Results The I sprays increased apple I contents to the targeted range of 50-100 $\mu \mathrm{g} 100 \mathrm{~g}^{-1}$ fresh weight and even to the recommended daily intake of I for adults (the
\end{abstract}

Responsible Editor: Ismail Cakmak.

Supplementary Information The online version contains supplementary material available at https://doi. org/10.1007/s11104-021-04992-z.

P. Wójcik ( $\square)$

Department of Fruit Crop Management and Plant Nutrition, The National Institute of Horticultural Research, Ul. Konstytucji 3 Maja 1/3, 96-100 Skierniewice, Poland e-mail: pawel.wojcik@inhort.pl

M. Wójcik

Department of Structural Biology, Medical University of Lodz, ul. Zeligowskiego 7/9, 95-752 Lodz, Poland e-mail: marzena.wojcik@umed.lodz.pl
KI sprays at rates of $1 \mathrm{~kg}$ and $1.5 \mathrm{~kg} \mathrm{I} \mathrm{ha}^{-1}$ ). Although the I sprays caused leaf injuries, they did not affect tree growth and yield. However, the spray of $\mathrm{KI}$ and $\mathrm{KIO}_{3}$ at the highest rate decreased the soluble solid concentration in fruit. For soil-supplied trees with I, an increase in apple I concentration was found only in the first year of the study.

Conclusions Apple tree is a suitable target plant for agronomic I biofortification, and from the economic point of view, the spray of $\mathrm{KI}$ or $\mathrm{KIO}_{3}$ at a rate of $0.5 \mathrm{~kg} \mathrm{I} \mathrm{ha}^{-1}$ should be recommended in orchards.

Keywords Agronomic biofortification - Apples Orchard $\cdot$ Iodine $\cdot$ Soil fertilization $\cdot$ Foliar sprays

$\begin{array}{ll}\text { Abbreviations } \\ \text { CH } & \text { Canopy height } \\ \text { DAS } & \text { Days after the iodine spray } \\ \text { DW } & \text { Dry weight } \\ \text { EDTA } & \text { Ethylenediaminetetraacetic acid } \\ \text { FF } & \text { Flesh firmness } \\ \text { FW } & \text { Fresh weight } \\ \text { IDD } & \text { Iodine deficiency disorders } \\ \text { POD } & \text { Point of deliquescence } \\ \text { RH } & \text { Relative humidity } \\ \text { SI } & \text { Starch index } \\ \text { SRM } & \text { Standard reference material } \\ \text { SSC } & \text { Soluble solid concentration } \\ \text { TA } & \text { Titratable acidity } \\ \text { TMAH } & \text { Tetra-methylammonium hydroxide } \\ \text { WAH } & \text { Weeks after harvest }\end{array}$




\section{Introduction}

Iodine (I) is an essential micronutrient for humans at all stages of life mainly due to its incorporation into thyroid hormones that regulate normal growth and development (Arthur and Beckett 1999; Hetzel 1983). In I deficiency, endemic goitres appear, and growth, reproductive and mental functions are impaired (Delange 2000; Dillon and Milliez 2000). The above disease complex is termed I deficiency disorder (IDD). It is estimated that nearly 2 billion people in the world are at risk of IDD (Ittermann et al. 2020; World Health Organization 2014). Approximately 50\% of the European population is mildly to moderately I deficient (Trofimiuk-Müldner et al. 2020).

Diet is the main source of I for humans (Gietka-Czernel 2015). To avoid IDD, it is necessary to regularly intake foods with adequate I quantities to cover the recommended dietary allowance (RDA), ranging from $90 \mu \mathrm{g} \mathrm{I} \mathrm{day}{ }^{-1}$ for children up to the age of 9 years to $250 \mu \mathrm{g} \mathrm{I}$ day $^{-1}$ for pregnant and lactating women (Zimmerman et al. 2008).

Iodisation of table salt is the most frequently applied approach to prevent and mitigate/eliminate IDD (Anderson et al. 2005; World Health Organization 2007). Although salt iodisation efficiently improves I nutrition, it is predicted that this approach will play a diminishing role in I prophylaxis in the future, at least in developed countries, as excess consumption of table salt results in the development of cardiovascular diseases (Gietka-Czernel 2015; He and MacGregor 2009; Strazzullo et al. 2009). The I intake rate from salt is also difficult to control because $\mathrm{I}$ is lost as a result of volatilisation during salt transport and storage, as well as in the processes of boiling, streaming, frying and roasting food (Winger et al. 2008).

It is believed that the primary factor determining IDD is a low I concentration in the Earth's crust, resulting in the production of I-deficient crops (Fuge 1996; Weng et al. 2009). According to White and Broadley (2009), enrichment of edible plant parts with I via root or leaf application is a fast, low-cost method of biofortification. Research reviews on the impacts of different modes of I use on vegetative and yield responses and on I enrichment of edible plant parts for various species have been presented by Medrano-Macias et al. (2016) and Gonzali et al.
(2017). According to those authors, plant supplementation with I must take into account the plant species/variety, the cultivation system or technology, the growth conditions related to climate and growing medium and the rate, mode of use and chemical form of I.

Among deciduous fruit trees, the efficiency of agronomic I biofortification has been examined only for plum (Prunus domestica L.), nectarine (Prunus persica L. Batsch.), pear (Pyrus communis L.) and apple (Malus domestica Borth.) trees (Budke et al. 2020a, 2021; Caffagni et al. 2012). In particular, apples appear to be good targets for I biofortification because they are widely consumed throughout the world and have high contents of dietary antioxidants that play an important role in human health (Boyer and Liu 2004). In the study on apple trees grown under a plastic tunnel, Budke et al. (2020a) found that two sprays of potassium iodide (KI) at the concentration of $0.098 \%(\mathrm{w} / \mathrm{v})$ were successful in biofortifying fruit with I. Simultaneously, applications of KI or K-iodate $\left(\mathrm{KIO}_{3}\right)$ to peat-based substrate in which trees grew were not able to effectively increase apple I concentrations. In a subsequent study by Budke et al. (2021), carried out in 'Jonagold' and 'Fuji' apple orchards, the authors found that the I sprays applied two times in the summer or once 2 weeks before harvest at rates of $0.25-2.5 \mathrm{~kg}$ I [ha meter canopy height - $(\mathrm{CH})^{-1}$ ] were able to increase apple I concentrations to about $200 \mu \mathrm{g} 100 \mathrm{~g}^{-1}$ fresh weight (FW). Despite these promising results, the assessment of the efficiency of I biofortification through soil application has not yet been established for apple trees. Furthermore, a quality assessment of apples was restricted only to the mean weight and soluble solid concentration (SSC) in fruit flesh, with no measurement of other external and internal quality parameters (e.g. skin rusetting and blushing, acid content), which are crucial regarding the commercial quality of apples and their taste (Nosecka and Zaremba 2019). Thus, these issues should be addressed in subsequent agronomic biofortification studies.

The main purpose of the present study was to examine the impact of high rates of soil and foliar I applications on I uptake by mature 'Red Jonaprince' apple trees grown in a high-density orchard. Our previous studies have shown that the use of a single calcium (Ca) spray in pear and apple orchards just 
before harvest at high rates was more successful in improving fruit $\mathrm{Ca}$ than several sprays of this nutrient at lower doses in the early stages of the development/growth of fruit (Wójcik 2001; Wójcik et al. 2014).

In this study, we also sought to assess the vegetative and yield responses of trees and apple quality to the above I treatments. Because the applied I rates were high for soil treatments and sprays, we determined several essential plant parameters linked to the photosynthetic activity of leaves (i.e. defoliation, cold bud injury, tree vigour and yielding, fruit size and blushing, and fruit contents of organic acids and soluble carbohydrates), which could be potentially reduced by I toxicity (Johnson 1980). Such an approach is appropriate before implementation of fertiliser recommendations in orchards.

\section{Materials and methods}

Study location and plant material

The study was conducted in 2018-2019 at a commercial 'Red Jonaprince' apple orchard in Central Poland $\left(51^{\circ} 48^{\prime} \mathrm{N}, 20^{\circ} 51^{\prime} \mathrm{E}\right.$ longitude; $162 \mathrm{~m}$ above sea level; approximately $280 \mathrm{~km}$ from the Baltic sea coast). The mean annual air temperature and total precipitation in this region were $4.9^{\circ} \mathrm{C}$ and $535 \mathrm{~mm}$ in 2018 , and $6.0{ }^{\circ} \mathrm{C}$ and $476 \mathrm{~mm}$ in 2019 , respectively. During the vegetative period (May-October), the average temperature was $16.5{ }^{\circ} \mathrm{C}$ in 2018 and $16.4{ }^{\circ} \mathrm{C}$ in 2019 , and the total rainfall was $381 \mathrm{~mm}$ in 2018 and $306 \mathrm{~mm}$ in 2019.

Experimental apple trees/M.9 were planted in the spring of 2014 in north-south oriented single rows (each $100 \mathrm{~m}$ long) at a spacing of $3.5 \times 1.2 \mathrm{~m}$ $\left(2,381\right.$ trees $\left.\mathrm{ha}^{-1}\right)$. Trees were trained as a spindle (with the canopy from $0.6 \mathrm{~m}$ to $3.0 \mathrm{~m}$ ) by annual spring pruning performed according to the renewal method (Mika and Buler 2015). Lateral branches were bent with strings and fastened to the trunk at a $40-50^{\circ}$ angle from the vertical. A single ornamental 'Golden Hornet' (Malus $x$ zumi) tree as a source of additional pollen (pollinators) was planted at the beginning and end of each apple tree row. To enable adequate fruit set, a few days before the onset of 'Red Jonaprince' tree bloom, two beehives were introduced into the field.

During the study, 2-3 days before petal fall $(\mathrm{BBCH}$ 64-65), the flowers were chemically thinned by means of ammonium thiosulphate fertiliser (ATS) at a rate of $12 \mathrm{~kg} \mathrm{ha}^{-1}$, using $500 \mathrm{~L}$ water. Additionally, in the summer (approximately 3 months before harvest), small, scarred, blemished and/or deformed fruitlets were aborted by hand. Neither foliar fertilisers nor growth stimulants/regulators were applied. The control of pathogens and pests was performed according to up-to-date recommendations for integrated apple production (Sobiczewski et al. 2018).

From early spring until the end of currentseason shoot growth, 1.0-m-wide herbicide strips were maintained along the tree rows by the use of post-emergence herbicides. There was mowed sod between the rows. From May to September, trees were surface drip-irrigated to maintain soil moisture near field capacity to a depth of $30 \mathrm{~cm}$. One irrigation line with emitters placed every $60 \mathrm{~cm}$ (each delivering $3 \mathrm{Ll}$ water $\mathrm{h}^{-1}$ ) was stretched along each tree row at a distance of approximately $20 \mathrm{~cm}$ from the trunks. The doses of water used per tree were $371 \mathrm{~L}$ in 2018 and $423 \mathrm{~L}$ in 2019.

Apple trees were supplied annually with nitrogen $(\mathrm{N})$ as ammonium nitrate $\left(\mathrm{NH}_{4} \mathrm{NO}_{3} ; 34 \% \mathrm{~N}\right.$; Anwil S.A., Włocławek, Poland) and potassium (K) as $\mathrm{K}$-sulphate $\left(\mathrm{K}_{2} \mathrm{SO}_{4} ; 42 \% \mathrm{~K} ; \mathrm{K}+\mathrm{S}\right.$ Kali $\mathrm{GmbH}$, Kassel, Germany). The fertilisers were broadcast over the surface of the herbicide strips at a rate of $70 \mathrm{~kg} \mathrm{~N} \mathrm{ha}^{-1}$ and $90 \mathrm{~kg} \mathrm{~K} \mathrm{ha}^{-1}$. Fertiliser $\mathrm{K}$ was applied at the swollen-breaking bud stage $(\mathrm{BBCH}$ 03-07), while $\mathrm{N}$ was applied at two equal rates: the first dose was used combined with fertiliser $\mathrm{K}$ and the second immediately after bloom (BBCH 67-69). The rates of $\mathrm{N}$ and $\mathrm{K}$, and the timing of their use were in accordance with the recommendations of Wójcik (2009) for mature apple trees grown in high-density orchards in soils with a moderate status of organic matter and optimal $\mathrm{K}$ availability.

\section{Soil conditions}

The experimental apple trees grew in brown soil (Cambisols). Prior to soil application of fertiliser N, $\mathrm{K}$ and I, soil samples were taken in the early spring of 2018 (beginning of bud swelling - BBCH 01), from 
each plot from a depth of 0-30 $\mathrm{cm}$, approximately $20 \mathrm{~cm}$ from the dripper. In all soil samples, the carbon (C) content was $18 \mathrm{~g} \mathrm{~kg}^{-1}$, the bulk density was $1.6 \mathrm{~g} \mathrm{~cm}^{-3}$, and particles of sand $(0.05-2 \mathrm{~mm})$, silt $(0.002-0.05 \mathrm{~mm})$ and clay $(<0.002 \mathrm{~mm})$ comprised $56 \%, 32 \%$ and $12 \%$, respectively. Across the experimental plots, soil reaction values $(\mathrm{pH})$ varied from 6.5 to 6.7 , while the concentration ranges of active oxides of iron $(\mathrm{Fe})$, aluminium $(\mathrm{Al})$ and manganese (Mn) were $3.5-3.8 \mathrm{~g} \mathrm{~kg}^{-1}, 1.9-2.1 \mathrm{~g} \mathrm{~kg}^{-1}$ and $13-18 \mathrm{mg} \mathrm{kg}^{-1}$, respectively. Concentrations of available essential macro- and micronutrients in the soil samples were as follows: $15-22 \mathrm{mg} \mathrm{N}-\mathrm{NH}_{4}{ }^{+}+\mathrm{NO}_{3}{ }^{-}$, 41-45 mg phosphorus (P), 98-102 mg K, 40-45 mg magnesium (Mg), 615-645 mg Ca, 61-68 mg Fe, 41-49 mg Mn, 7.1-8.2 mg zinc ( $\mathrm{Zn}), 4.1-4.5 \mathrm{mg}$ copper $(\mathrm{Cu})$ and $1-1.2 \mathrm{mg}$ boron (B) $\mathrm{kg}^{-1}$ of soil. The total and water-soluble I concentrations in soil ranged from 2.6 to $2.9 \mathrm{mg} \mathrm{kg}^{-1}$ (arithmetic mean $2.7 \mathrm{mg} \mathrm{kg}^{-1}$, variability coefficient $4 \%$ ) and from 0.15 to $0.18 \mathrm{mg} \mathrm{kg}^{-1}$ (arithmetic mean $0.16 \mathrm{mg} \mathrm{kg}^{-1}$, variability coefficient $8 \%$ ), respectively.

The particle contributions of sand, silt and clay in soil were determined by the aerometric method of Casagrande and Prószynski (described by Ostrowska et al. 1991). The organic matter was determined by the dry combustion method at a temperature of $950{ }^{\circ} \mathrm{C}$ in the presence of pure oxygen (Allison 1965). The bulk density was determined according to the core method (Mercik 2004). The $\mathrm{pH}$ was measured by the potentiometrical method at a ratio of one part airdried soil to 2.5 parts $1 \mathrm{M} \mathrm{KCl}$ after shaking for $1 \mathrm{~h}$ (Ostrowska et al. 1991). Fe/Al-oxides and Mn-oxides were extracted with $\mathrm{NH}_{4}$-oxalate solution and hydroxylamine hydrochloride solution $\left(\mathrm{NH}_{2} \mathrm{OH}-\mathrm{HCl}\right)$, respectively (Chao 1972; Jin et al. 1987). Essential macro- and micronutrients were extracted by means of a solution of $0.03 \mathrm{~N}$ acetic acid containing ethylenediaminetetraacetic acid (EDTA) according to the procedure given by Nowosielski (1988). Total and water-soluble I according were determined to the method described by Watts and Mitchell (2009). Soil nutrients were expressed on a dry weight (DW) basis.

Organic $\mathrm{C}$ was determined by means of a Leco TruSpec CNS analyser (Leco Corp., St. Joseph, MI, USA), $\mathrm{NO}_{3}{ }^{-}$and $\mathrm{NH}_{4}{ }^{+}$ions were determined using a continuous flow analyser (Skalar Sanplus; Skular Analytical B.V.; AA Breda, Netherlands). Other essential nutrients were determined by inductively coupled plasma optical emission spectrometry (ICP-OES; Thermo Jarrell Ash, Franklin, MA, USA). Iodine was determined by means of inductively coupled plasma mass spectrometry (X-Series II ICP-MS; Thermo Fisher Scientific, Waltham, MA, USA).

Treatments and experimental layout

The tested I treatments included soil applications and preharvest sprays. Iodine was used as KI (powder, $76.5 \%$ I; Sigma-Aldrich, Poznań, Poland) and $\mathrm{KIO}_{3}$ (crystals, 59.3\% I; Sigma-Aldrich, Poznań, Poland), which are the most frequently used I sources in studies (Gonzali et al. 2017; Hong et al. 2009; Lawson et al. 2015; Medrano-Macias et al. 2016). Soil I application was made only in 2018 at the swollen-breaking bud stage (BBCH 03-07) via uniformly broadcasting mixed $\mathrm{N}, \mathrm{K}$ and I fertilisers over the surface of the herbicide strips at rate of $4 \mathrm{~kg}, 8 \mathrm{~kg}$ or $12 \mathrm{~kg} \mathrm{I} \mathrm{ha}^{-1}$ (corresponding to $0.83 \mathrm{mg}, 1.66 \mathrm{mg}$ and $2.49 \mathrm{mg} \mathrm{I}$ $\mathrm{kg}^{-1}$ of soil, respectively, for the depth of $0-30 \mathrm{~cm}$ ). Iodine sprays were performed annually, 2 weeks before harvest - BBCH 81 (on 9 September 2018 and 12 September 2019) at rate of $0.5 \mathrm{~kg}, 1 \mathrm{~kg}$ or $1.5 \mathrm{~kg} \mathrm{I} \mathrm{ha}^{-1}$, which corresponds to $0.21 \mathrm{~kg}, 0.42 \mathrm{~kg}$ and $0.63 \mathrm{~kg}$ (ha $\cdot \mathrm{m} \mathrm{CH}^{-1}$, respectively. Five hundred litres of water were used in each I spray [208 L (ha $\cdot \mathrm{m}$ $\mathrm{CH})^{-1}$ ]. To improve wetting of leaf and fruit surfaces, the non-ionic surfactant Tween ${ }^{\circledR} 20$ (polyoxyethylene sorbitan monolaurate; Sigma-Aldrich, St. Louis, Missouri, USA) was added to each spray solution at a rate of $0.3 \mathrm{~L}(0.06 \% \mathrm{v} / \mathrm{v})$. The I sprays were applied to both sides of tree rows, in the morning (between 10:00 $\mathrm{h}$ and 11:00 $\mathrm{h}$ at an average air temperature and humidity of $10{ }^{\circ} \mathrm{C}$ and $69 \%$ in 2018 and $12{ }^{\circ} \mathrm{C}$ and $72 \%$ in 2019 , respectively) by means of a motorised backpack sprayer (Solo 433H, Kleinmotoren GmbH, Sindelfingen, Germany), equipped with a flat fan jet nozzle and using a pressure of $10 \mathrm{Bar}$. Trees sprayed only with water solution containing Tween 20 adjuvant served as the control.

Over the entire experimental period, the same trees were used for the given I treatments. The study was conducted using a completely randomised block design with three replications, with a replicate of each combination within one row. Each plot consisted of seven trees. Plots within a row were separated by one tree. There was a buffer row between experimental rows. 
Measurements and observations.

Soil I

Total and water-extractable I were determined only from soil-treated plots with I and control plots. Soil samples were taken in 2019, 2 weeks after harvest (558 $\mathrm{d}$ after the soil I treatments), $20 \mathrm{~cm}$ from the dripper (outside the wetted soil zone) from a depth of 0-30 cm, using a Dutch auger with a 3-cm diameter (Eijkelkamp, Giesbeek, the Netherlands). The composite sample from each plot consisted of three subsamples.

Total and water-soluble I in soil were determined in the same way as prior to the soil I application. Briefly, for determination of total I, a $0.25 \mathrm{~g}$ air-dried soil sample was suspended in $5 \mathrm{ml} \mathrm{5 \%}$ tetra-methylammonium hydroxide (TMAH) solution in $15-\mathrm{ml}$ polycarbonate centrifuge tubes. The tubes were heated to $70{ }^{\circ} \mathrm{C}$ for $3 \mathrm{~h}$. After cooling, $5 \mathrm{ml}$ deionised water was added to the tubes, which were then centrifuged at $2500 \mathrm{rpm}$ for $20 \mathrm{~min}$. The supernatant was filtered through a $0.24 \mu \mathrm{m}$ membrane filter and diluted to a final matrix of $1 \%$ TMAH. To determine water-soluble I, a $1.25 \mathrm{~g}$ air-dried soil sample was mixed with $12.5 \mathrm{ml}$ deionised water in 15-ml tubes and then shaken for $15 \mathrm{~min}$. The tubes were centrifuged at $3000 \mathrm{rpm}$ for $10 \mathrm{~min}$. and the solution was filtered and adjusted to a matrix of $1 \%$ TMAH. Iodine was detected by ICP-MS using an internal standard of $1 \mathrm{mg} / \mathrm{L}$ tellurium (Te).

Loss of exogenously applied I from the surface soil layer was determined after two cropping seasons by subtracting from the used I rate (expressed as mg $\mathrm{kg}^{-1}$ soil) the difference in total I concentration in soil between the given I-enriched plots and the control plot.

\section{Tree I}

Iodine was determined in pooled samples of leaves, edible fruit parts (skin plus flesh) or seeds for each experimental plot (replicate). Leaves for analysis were taken $20 \mathrm{~d}$ after harvest from the mid-portion of the current-season shoots located at the peripheral zone of the tree crown. Samples from each plot consisted of 100 leaves (with pedicels). Iodine in edible apple parts and seeds was determined on 30 fruits of similar size, taken randomly from a $20-\mathrm{kg}$ bulk sample from the plot. Seeds were taken only from soil-supplied plots with I and from control plots because it was assumed that: (i) I taken up by roots could be transported into fruit, including seeds as has been proved by Weng et al. (2008) and Kiferle et al. (2013) for cucumber (Cucumis sativus L.), eggplant (Solanum melongena L.) and tomato (Solanum lycopersicum L.), and (ii) I sprays 2 weeks before harvest are not able to increase seed I because of reduced transport from apple peel cells, through the cortical flesh, up to the core as has been documented in several studies for radionuclides and $\mathrm{Ca}$ ions (Carini and Bengtsson 2001; Harker et al. 1988; Rosen et al. 2006; Van Goor 1973).

Apples and leaves were gently rinsed with $0.01 \mathrm{M}$ $\mathrm{HCl}$ and then with double-deionised water in order to remove I spray residues from the epicuticular wax layer as previously documented in respect to a B contamination of fruits and leaves of apple trees sprayed with boric acid solutions (Wójcik 1999).

From each fruit on opposite sides, two radial, 2-cm-thick slices up to the outer limit of the carpel were cut out and weighed.

Only well-formed seeds were taken for analysis. Seeds were washed only with deionised water, dried with a paper towel and then weighted.

Samples of leaves, edible fruit parts and seeds were dried at $60{ }^{\circ} \mathrm{C}$ in a forced-draft oven (model UT 6760, Heraeus, Hanau, Germany) until a constant weight, weighed (except for leaves) and ground in a Wiley stainless steel mill to pass through a 40-mesh screen.

Iodine was determined according to the procedure recommended by the Polish Committee for Standardization (PN-EN 15111 2008). Briefly, into 30-ml Falcon tubes $0.5 \mathrm{~g}$ dried plant material, $15 \mathrm{ml}$ distilled water and $1 \mathrm{ml} 25 \%$ TMAH were added. After thorough mixing, the samples were heated at $90{ }^{\circ} \mathrm{C}$ for $3 \mathrm{~h}$. Then, the tubes were filled with deionised water, mixed, centrifuged at $4500 \mathrm{rpm}$ for $15 \mathrm{~min}$ and filtered through a $0.24 \mu \mathrm{m}$ membrane. The concentration of ${ }^{127} \mathrm{I}$ was measured with ICP-MS using an internal standard of $1 \mathrm{mg} / \mathrm{L} \mathrm{Te}$.

To control the analytical quality, standard reference materials (apple leaves containing $0.30 \mathrm{mg}$ I $\mathrm{kg}^{-1}$ DW-SRM 1515 and tomato leaves containing $0.85 \mathrm{mg} \mathrm{I} \mathrm{kg}^{-1} \mathrm{DW}-\mathrm{SRM}$ 1573a] provided by the National Institute of Standards and Technology (Gaithersburg, MD, USA) were used. 
Measured I concentrations in in these samples were $0.29 \mathrm{mg} \mathrm{kg}^{-1} \pm 0.01 \mathrm{DW}$ for apple leaves and $0.82 \mathrm{mg} \mathrm{kg}^{-1} \pm 0.02 \mathrm{DW}$ for tomato leaves.

The iodine concentration was expressed on a DW basis in leaves and on a FW basis in edible fruit parts and seeds. The average DW contents in the analysed leaves, edible apple parts and seeds were $11.6 \%$, $16.8 \%$ and $62.3 \%$, respectively.

Leaf damage and chlorophyll concentration

Leaf injury was evaluated $4 \mathrm{~d}$ after the I spray treatments (166 d and $534 \mathrm{~d}$ after soil I application) and 3 weeks after harvest (197 d and $565 \mathrm{~d}$ after the soil I treatments), on approximately 100 leaves from each plot, taken from 1-year-old shoots located on the outside of the tree canopy. Leaves (without stems) were scanned using a digital image analysis system (WinDIAS 3.3., Delta-T Devices Ltd, Burwell, Cambridge, UK). Leaf injury was expressed as the percent area of chlorosis/necrosis in relation to the total blade area.

Leaf chlorophyll was assessed with a hand-held SPAD-502 Chlorophyll Meter (Minolta Camera Co., Ltd., Osaka, Japan), which calculates an index value based on the absorbance of light at wavelengths of $650 \mathrm{~nm}$ and $940 \mathrm{~nm}$. SPAD readings were taken on the same leaf samples used for the determination of leaf damage. Two measurements of each leaf blade were recorded on its opposite sides at the halfway point between the tip and lamina base, $1 \mathrm{~cm}$ from the edge.

\section{Defoliation and cold bud injury}

Defoliation was evaluated three times per season: the first time when $5 \%-10 \%$ of the leaves from the control trees had fallen (on 7 November 2018 and 13 November 2019) and next 20 and 30 days later. Defoliation was assessed on 40 labelled 1-year-old shoots per plot, located outside of the tree crown. The results were expressed as a percentage of fallen leaves.

Cold bud damage was evaluated on 20 current-season shoots per plot located at a height of 1.5-2.0 m above ground. The shoots were excised at the end of February 2019 and 2020 and kept for $14 \mathrm{~d}$ at room temperature. Then, buds were dissected vertically. Cold injury was evaluated based on cross section colour; green indicates a lack of bud damage, and brown indicates bud injury.
Cold bud damage was expressed as the percentage of browned buds.

Tree growth and fruit yield

Tree growth was assessed based on mean leaf blade area and total length of the current-season shoots per tree. Mean leaf area was measured 3 weeks after harvest on the samples used to determine leaf injury, using the WinDIAS Leaf Image Analysis System. The length of the current-season shoots was measured within the entire canopy of five randomly selected trees from each plot following completion of shoot growth.

The total fruit yield was weighed separately for each plot. Apples were picked at commercial maturity (on 23 September 2018 and 26 September 2019), evaluated based on measurement of the starch index (SI) and flesh firmness (FF) of apples from the control trees. According to the recommendations of the Department of Storage and Processing of Fruits and Vegetables, the Research Institute of Horticulture in Skierniewice (Poland), optimal values of the SI and FF of 'Red Jonaprince' apples at harvest are 5-7 and $75-85 \mathrm{~N}$, respectively.

Fruit quality attributes

Fruit quality traits included mean weight, skin russeting and colouring, FF, SI, SSC and titratable acidity (TA). Mean fruit weight, russeting and blushing were calculated/assessed on a $20-\mathrm{kg}$ bulk fruit sample from each plot. The other parameters were determined on 30 similarly sized fruit, taken randomly from each of the $20-\mathrm{kg}$ fruit samples per plot. Skin russeting and colouring were rated on a scale from 1 (no russeting/blushing) to 5 (russeting/blushing over $75 \%$ of the skin surface). Firmness was measured on two opposite peeled sides of each fruit, using a penetrometer (Model FR-5120, Lutron Electronic Enterprise Co., Ltd., Taipei, Taiwan) equipped with an 11-mmdiameter plunger. The SI was determined on a 3-mm equatorial slice by an iodine test, using a scale from 1 (100\% hue of the cross-sectional area of the fruit) to $10(0 \%$ hue). The soluble solid concentration was measured using an electronic refractometer (model HI 6801, Hanna Instruments Inc., Woonsocket, RI, USA) in a juice at $20^{\circ} \mathrm{C}$. Titratable acidity was determined 
by titrating the fruit homogenate with $0.1 \mathrm{~N} \mathrm{NaOH}$ to $\mathrm{pH} 8.1$, using an automatic titrator Mettler Toledo DL 50 Graphix (Mettler-Toledo AG., Schwerzenbach, Switzerland). The results of the TA represent the malic acid content expressed as a percentage.

\section{Statistical analysis}

All plant parameters were subjected to a one-way analysis of variance because different I rates were used in the spray combinations and in the soil treatments. For the combinations in which I was applied to soil, total and water-soluble I in soil and loss of used I from the top soil were subjected to two-way analysis of variance because the $\mathrm{I}$ rates for $\mathrm{I}^{-}$and $\mathrm{IO}_{3}{ }^{-}$were the same. The data of the total length of 1 -year-old shoots per tree were transformed according to $\mathrm{y}=\log \mathrm{x}$ and leaf damage, defoliation and cold bud injury according to $\mathrm{y}=\operatorname{arc} \sin \mathrm{x}$ (Szczepański and Rejman 1987). Values of the above parameters, provided in tables, were back-transformed. The data in tables are given as the mean \pm standard deviation (SD) of three replicates. The analyses were performed separately for each growing season using Duncan's multiple range test at $\mathrm{P} \leq 0.05$ by means of Statistica 10 software (StatSoft Polska, Krakow, Poland).

\section{Results}

Soil I

After two cropping seasons following the soil I treatments, soil on I-supplied plots contained more total and water-extractable I than that from control plots (Table 1). Total I concentrations in soil on all $\mathrm{I}^{-}$-treated plots and on $\mathrm{IO}_{3}{ }^{-}$-supplied plots at the lowest rate $\left(4 \mathrm{~kg} \mathrm{I} \mathrm{ha}^{-1}\right)$ were similar $\left(3.2-3.3 \mathrm{mg} \mathrm{kg}^{-1}\right.$ and $3.2 \mathrm{mg} \mathrm{kg}^{-1}$, respectively). Higher total I concentrations in soil compared with the above combinations were found on $\mathrm{IO}_{3}{ }^{-}$-enriched plots at doses of 8 and $12 \mathrm{~kg} \mathrm{I} \mathrm{ha}^{-1}$, wherein the use of $12 \mathrm{~kg} \mathrm{I} \mathrm{ha}^{-1}$ led to the strongest increase in total soil I $\left(5.2 \mathrm{mg} \mathrm{kg}^{-1}\right)$. Regardless of the I species used and its rate, I-supplemented plots contained comparable water-soluble I concentrations in soil $\left(0.24-0.28 \mathrm{mg} \mathrm{kg}^{-1}\right)$.

After two cropping seasons, loss of exogenously applied I from the top soil was affected by its species and rate (Table 1). Iodine loss on plots treated with $4 \mathrm{~kg} \mathrm{I} \mathrm{ha}^{-1}$ were the same for both studied species $\left(0.23 \mathrm{mg} \mathrm{kg}^{-1}\right)$. On plots supplied with $\mathrm{Kl}$ at higher rates, loss of this nutrient increased up to $1.89 \mathrm{mg} \mathrm{kg}^{-1}$. The above relationship was not found for $\mathrm{KIO}_{3}$. Moreover, after two cropping seasons on plots enriched with $\mathrm{KIO}_{3}$ at a rate of $12 \mathrm{~kg} \mathrm{I} \mathrm{ha}^{-1}$, the

Table 1 Changes in soil iodine (I) at 0-30 cm depth in 'Red Jonaprince' apple orchard after two cropping seasons following soil application of I in different forms (F) and doses (D)

\begin{tabular}{lllll}
\hline Iodine form & $\begin{array}{l}\text { Dose } \\
\left(\mathrm{kg} \mathrm{I} \mathrm{ha}^{-1}\right)\end{array}$ & \multicolumn{2}{l}{ Soil I concentration $\left(\mathrm{mg} \mathrm{kg}^{-1}\right)$} & I loss* \\
\cline { 2 - 3 } & & Total I & Water-soluble I & $+0.23 \pm 0.04 \mathrm{c}$ \\
\hline Potassium iodide & 4 & $3.2 \pm 0.3 \mathrm{~b}$ & $0.24 \pm 0.04 \mathrm{~b}$ & $+0.96 \pm 0.16 \mathrm{~d}$ \\
& 8 & $3.3 \pm 0.4 \mathrm{~b}$ & $0.25 \pm 0.03 \mathrm{~b}$ & $+1.89 \pm 0.20 \mathrm{e}$ \\
Potassium iodate & 12 & $3.2 \pm 0.3 \mathrm{~b}$ & $0.24 \pm 0.03 \mathrm{~b}$ & $+0.23 \pm 0.07 \mathrm{c}$ \\
& 4 & $3.2 \pm 0.3 \mathrm{~b}$ & $0.26 \pm 0.04 \mathrm{~b}$ & $+0.06 \pm 0.05 \mathrm{~b}$ \\
Control & 8 & $4.2 \pm 0.2 \mathrm{c}$ & $0.28 \pm 0.02 \mathrm{~b}$ & $-0.11 \pm 0.03 \mathrm{a}$ \\
\hline
\end{tabular}

Significance:

For total I: F**, D**, F x D**

For water-soluble I: F not significant (ns), D**, F x D ns

For I loss: $\mathrm{F}^{* *}, \mathrm{D}^{* *}, \mathrm{~F}$ x D $\mathrm{D}^{* *}$

Means with the same letter within each column are not significantly different by Duncan's multiple range test at $\alpha=0.05$

I loss was calculated by subtracting from the used I rate the difference in total I concentration in soil between the given I-enriched plots and the control plot

Probability levels of $F$ statistic for tested effects in ANOVA at $\mathrm{P} \leq 0.01$ 
amount of I in the soil was even higher than expected based on the rate used.

\section{Leaf and fruit I}

The effects of the soil I treatments on the leaf I concentration differed between the years (Table 2). In 2018, in which the soil I treatments were carried out, leaf I concentrations increased from $0.42 \mathrm{mg} \mathrm{kg}^{-1}$ to $0.79 \mathrm{mg} \mathrm{kg}^{-1} \mathrm{DW}$ as the application rates increased. In the next year, leaves from soil-I-supplemented-trees (regardless of the I form and rate used) contained comparable I concentrations $\left(0.39-0.41 \mathrm{mg} \mathrm{kg}^{-1} \mathrm{DW}\right)$. In general, the I sprays were more efficient than the soil I treatments in improving leaf I concentrations (Table 2). The effects of the $\mathrm{KIO}_{3}$ sprays on leaf I concentrations were not affected by the rate applied, while the efficiencies of the KI sprays increased as the dose increased. In both years, the highest leaf I was found on trees sprayed with $\mathrm{KI}$ at a rate of $1.5 \mathrm{~kg} \mathrm{I} \mathrm{ha}^{-1}$.

Only in 2018 the soil I treatments were able to improve I concentrations in edible fruit parts (referred to in the following part as fruit). Their efficiencies increased as the I application rate increased (Table 2). Moreover, the $\mathrm{KI}$ and $\mathrm{KIO}_{3}$ soil treatments used at the same I rate had comparable impacts on the fruit I concentration (2.8-12.0 $\mu \mathrm{g} 100 \mathrm{~g}^{-1} \mathrm{FW}$ and 2.1-2.3 $\mu \mathrm{g} 100 \mathrm{~g}^{-1}$ FW for the KI treatments vs 2.7-12.9 $\mu \mathrm{g} 100 \mathrm{~g}^{-1}$ FW and 1.9-2.1 $\mu \mathrm{g} 100 \mathrm{~g}^{-1} \mathrm{FW}$ for the $\mathrm{KIO}_{3}$ treatments in 2018 and 2019, respectively). In both years the I sprays were more successful in improving fruit I than the soil I treatments (Table 2). The efficiencies of the KI sprays in improving the fruit I concentration corresponded positively to the I amount used, while the effects of the $\mathrm{KIO}_{3}$ sprays were not affected by the I dose. Fruit I concentrations from KI-sprayed trees at a rate of $0.5 \mathrm{~kg} \mathrm{I}$ $\mathrm{ha}^{-1}$ were comparable to those from $\mathrm{KIO}_{3}$-sprayed trees at all rates used. The highest fruit I concentration was found for the KI spray at a rate of $1.5 \mathrm{~kg} \mathrm{I} \mathrm{ha}^{-1}\left(198.1 \mu \mathrm{g} 100 \mathrm{~g}^{-1} \mathrm{FW}\right.$ in 2018 and $231.6 \mu \mathrm{g} 100 \mathrm{~g}^{-1} \mathrm{FW}$ in 2019).

The soil I treatments enhanced seed I concentrations, although this effect only occurred in 2018 (Table 2). Regardless of the I species used and its rate, the efficiencies of the soil I treatments in improving seed I concentrations were comparable, ranging from $20.5 \mu \mathrm{g} 100 \mathrm{~g}^{-1} \mathrm{FW}$ to $23.2 \mu \mathrm{g}$ $100 \mathrm{~g}^{-1}$ FW.

Table 2 Effects of different strategies of iodine (I) application on concentration of this nutrient in selected tissues/organs of 'Red Jonaprince' apple trees

\begin{tabular}{|c|c|c|c|c|c|c|c|}
\hline \multirow[t]{2}{*}{ Treatment } & \multirow[t]{2}{*}{$\begin{array}{l}\text { I dose } \\
\left(\mathrm{kg} \mathrm{ha}^{-1}\right)\end{array}$} & \multicolumn{2}{|l|}{$\begin{array}{l}\text { Leaf I } \\
\left(\mathrm{mg} \mathrm{kg}^{-1} \mathrm{DW}\right)\end{array}$} & \multicolumn{2}{|c|}{$\begin{array}{l}\text { Fruit I } \\
\left(\mu \mathrm{g} 100 \mathrm{~g}^{-1} \mathrm{FW}\right)\end{array}$} & \multicolumn{2}{|c|}{$\begin{array}{l}\text { Seed I } \\
\left(\mu \mathrm{g} 100 \mathrm{~g}^{-1} \mathrm{FW}\right)\end{array}$} \\
\hline & & 2018 & 2019 & 2018 & 2019 & 2018 & 2019 \\
\hline \multirow{3}{*}{$\begin{array}{l}\text { Soil application of potassium } \\
\text { iodide }\end{array}$} & 4 & $0.42 \pm 0.02 b$ & $0.39 \pm 0.07 \mathrm{~b}$ & $2.8 \pm 0.3 b$ & $2.1 \pm 0.8 \mathrm{a}$ & $22.4 \pm 3.3 b$ & $15.6 \pm 1.0 \mathrm{a}$ \\
\hline & 8 & $0.54 \pm 0.02 \mathrm{c}$ & $0.41 \pm 0.10 \mathrm{~b}$ & $6.1 \pm 0.7 \mathrm{c}$ & $2.3 \pm 0.5 \mathrm{a}$ & $23.1 \pm 2.6 \mathrm{~b}$ & $17.5 \pm 1.3 \mathrm{a}$ \\
\hline & 12 & $0.79 \pm 0.09 \mathrm{~d}$ & $0.40 \pm 0.13 b$ & $12.0 \pm 3.2 \mathrm{~d}$ & $2.2 \pm 1.3 \mathrm{a}$ & $20.5 \pm 1.5 b$ & $16.7 \pm 2.0 \mathrm{a}$ \\
\hline \multirow{3}{*}{$\begin{array}{l}\text { Soil application of potassium } \\
\text { iodate }\end{array}$} & 4 & $0.42 \pm 0.04 \mathrm{~b}$ & $0.39 \pm 0.12 b$ & $2.7 \pm 0.4 \mathrm{~b}$ & $2.1 \pm 0.9 \mathrm{a}$ & $21.1 \pm 3.7 \mathrm{~b}$ & $14.6 \pm 2.1 \mathrm{a}$ \\
\hline & 8 & $0.52 \pm 0.03 \mathrm{c}$ & $0.40 \pm 0.14 \mathrm{~b}$ & $6.5 \pm 1.1 \mathrm{c}$ & $1.9 \pm 0.6 \mathrm{a}$ & $23.2 \pm 3.3 b$ & $13.8 \pm 1.3 \mathrm{a}$ \\
\hline & 12 & $0.75 \pm 0.06 \mathrm{~d}$ & $0.39 \pm 0.13 b$ & $12.9 \pm 2.4 \mathrm{~d}$ & $1.9 \pm 1.0 \mathrm{a}$ & $22.7 \pm 0.6 b$ & $14.3 \pm 0.8 \mathrm{a}$ \\
\hline \multirow[t]{3}{*}{ Spray of potassium iodide } & 0.5 & $2.05 \pm 0.15 \mathrm{e}$ & $2.13 \pm 0.23 \mathrm{c}$ & $73.9 \pm 4.3 \mathrm{e}$ & $94.1 \pm 14.8 b$ & $\mathrm{nd}^{*}$ & nd \\
\hline & 1.0 & $3.55 \pm 0.47 \mathrm{f}$ & $3.23 \pm 0.44 \mathrm{~d}$ & $132.6 \pm 24.0 \mathrm{f}$ & $158.5 \pm 19.1 \mathrm{c}$ & nd & nd \\
\hline & 1.5 & $5.48 \pm 0.62 \mathrm{~g}$ & $5.31 \pm 0.85 \mathrm{e}$ & $198.1 \pm 14.1 \mathrm{~g}$ & $231.6 \pm 22.6 \mathrm{~d}$ & nd & nd \\
\hline \multirow[t]{3}{*}{ Spray of potassium iodate } & 0.5 & $1.89 \pm 0.46 \mathrm{e}$ & $2.02 \pm 0.45 \mathrm{c}$ & $65.5 \pm 9.9 \mathrm{e}$ & $88.4 \pm 9.2 b$ & nd & nd \\
\hline & 1.0 & $1.91 \pm 0.33 \mathrm{e}$ & $2.10 \pm 0.42 \mathrm{c}$ & $71.2 \pm 11.3 \mathrm{e}$ & $95.7 \pm 10.6 \mathrm{~b}$ & nd & nd \\
\hline & 1.5 & $2.01 \pm 0.25 \mathrm{e}$ & $2.08 \pm 0.45 \mathrm{c}$ & $72.8 \pm 14.8 \mathrm{e}$ & $98.8 \pm 24.0 \mathrm{~b}$ & nd & nd \\
\hline Control & 0 & $0.26 \pm 0.03 \mathrm{a}$ & $0.23 \pm 0.03 \mathrm{a}$ & $1.9 \pm 0.2 \mathrm{a}$ & $2.0 \pm 1.3 \mathrm{a}$ & $15.7 \pm 1.9 \mathrm{a}$ & $14.8 \pm 2.6 \mathrm{a}$ \\
\hline
\end{tabular}

Means with the same letter within each column are not significantly different by Duncan's multiple range test at $\alpha=0.05$

*not determined 
Damages and tree growth and yield

Leaves from the control plots had no signs of injury (Table 3). None of the soil I treatments caused leaf blade damage (Table 3). In both tested time points, all I spray treatments led to leaf burning (Table 3). Leaf damage was manifested as necrosis along leaf edges and as small, irregular necrotic spots throughout the lamina, identical to those observed by Budke et al. (2020a, 2021) for apple leaves sprayed with I solutions. The intensities of I-sprayed leaf injuries for a given rate were comparable for both I species. The extent of leaf blade damage following the I sprays increased with increasing rates, achieving $20.1 \%$ in 2018 and $28.2 \%$ in 2019 for the $\mathrm{KIO}_{3}$ spray combination.

Soil I treatments had no effect on SPAD leaf reading values (Table 3 ). At the first time point, only the I sprays at rates of $1 \mathrm{~kg}$ and $1.5 \mathrm{~kg} \mathrm{ha}^{-1}$ decreased SPAD leaf readings, with the greatest decline at the highest rate used (Table 3). At the second time point, all I spray treatments decreased SPAD leaf readings, and their drop was related positively to the I rate (Table 3 ). The changes in SPAD leaf reading values for I-sprayed leaves did not depend on the I species used.

The soil I treatments and the I sprays at the lowest rate did not affect defoliation (Table 4). In all studied terms of defoliation, the I sprays at rates of $1 \mathrm{~kg}$ and $1.5 \mathrm{~kg} \mathrm{ha}^{-1}$ accelerated the leaf fall, and their effects were comparable (Table 4). In the above-mentioned spray treatments, both of the studied I species had similar effects on defoliation (on average $77 \%$ and $89 \%$ for KI vs $77 \%$ and $88 \%$ for $\mathrm{KIO}_{3}$ in 2018 and 2019, respectively).

In both years, cold bud damage was slight and did not exceed $5 \%$ of the total bud amount (Table 4). Under those conditions, the tested I treatments had no effect on cold bud injuries (Table 4).

Mean leaf area did not differ between combinations (Table 5). In addition, none of the studied I treatments affected the total length of current-season shoots per tree (Table 5).

Fruit yields per ha from the control trees were 54.3 tons in 2018 and 45.2 tons in 2019. The I treatments did not affect tree yields (Table 5).

Table 3 Effects of different strategies of iodine (I) supply of 'Red Jonaprince' apple trees on leaf injury and green colour intensity

\begin{tabular}{|c|c|c|c|c|c|c|c|c|c|}
\hline \multirow[t]{3}{*}{ Treatment } & \multirow{3}{*}{$\begin{array}{l}\text { I dose } \\
(\mathrm{kg} \\
\left.\mathrm{ha}^{-1}\right)\end{array}$} & \multicolumn{4}{|c|}{ Damaged area of leaf blade $(\%)$} & \multicolumn{4}{|c|}{ SPAD value $(0-80)$} \\
\hline & & \multicolumn{2}{|l|}{2018} & \multicolumn{2}{|l|}{2019} & \multicolumn{2}{|l|}{2018} & \multicolumn{2}{|l|}{2019} \\
\hline & & 4 DAS $^{*}$ & $3 \mathrm{WAH}^{* *}$ & 4 DAS & $3 \mathrm{WAH}$ & 4 DAS & $3 \mathrm{WAH}$ & 4 DAS & $3 \mathrm{WAH}$ \\
\hline \multirow{3}{*}{$\begin{array}{l}\text { Soil appli- } \\
\text { cation of } \\
\text { potassium } \\
\text { iodide }\end{array}$} & 4 & $0 \pm 0 \mathrm{a}$ & $0 \pm 0 \mathrm{a}$ & $0 \pm 0 \mathrm{a}$ & $0 \pm 0 \mathrm{a}$ & $43.0 \pm 0.7 \mathrm{c}$ & $41.3 \pm 0.2 \mathrm{~d}$ & $43.1 \pm 0.6 \mathrm{c}$ & $41.5 \pm 0.5 \mathrm{~d}$ \\
\hline & 8 & $0 \pm 0 \mathrm{a}$ & $0 \pm 0 \mathrm{a}$ & $0 \pm 0 \mathrm{a}$ & $0 \pm 0 \mathrm{a}$ & $42.8 \pm 0.4 \mathrm{c}$ & $41.5 \pm 0.5 \mathrm{~d}$ & $42.8 \pm 0.4 \mathrm{c}$ & $41.4 \pm 0.6 \mathrm{~d}$ \\
\hline & 12 & $0 \pm 0 \mathrm{a}$ & $0 \pm 0 \mathrm{a}$ & $0 \pm 0 \mathrm{a}$ & $0 \pm 0 \mathrm{a}$ & $42.9 \pm 0.4 \mathrm{c}$ & $41.7 \pm 0.5 \mathrm{~d}$ & $42.9 \pm 0.2 \mathrm{c}$ & $41.6 \pm 0.6 \mathrm{~d}$ \\
\hline \multirow{3}{*}{$\begin{array}{l}\text { Soil appli- } \\
\text { cation of } \\
\text { potassium } \\
\text { iodate }\end{array}$} & 4 & $0 \pm 0 \mathrm{a}$ & $0 \pm 0 \mathrm{a}$ & $0 \pm 0 \mathrm{a}$ & $0 \pm 0 \mathrm{a}$ & $43.0 \pm 0.3 \mathrm{c}$ & $41.8 \pm 0.5 \mathrm{~d}$ & $43.0 \pm 0.3 \mathrm{c}$ & $41.6 \pm 0.5 \mathrm{~d}$ \\
\hline & 8 & $0 \pm 0 \mathrm{a}$ & $0 \pm 0 \mathrm{a}$ & $0 \pm 0 \mathrm{a}$ & $0 \pm 0 \mathrm{a}$ & $42.7 \pm 0.6 \mathrm{c}$ & $41.6 \pm 0.4 \mathrm{~d}$ & $42.7 \pm 0.4 \mathrm{c}$ & $41.5 \pm 0.5 \mathrm{~d}$ \\
\hline & 12 & $0 \pm 0 \mathrm{a}$ & $0 \pm 0 \mathrm{a}$ & $0 \pm 0 \mathrm{a}$ & $0 \pm 0 \mathrm{a}$ & $42.6 \pm 0.4 \mathrm{c}$ & $41.7 \pm 0.3 \mathrm{~d}$ & $43.0 \pm 0.5 \mathrm{c}$ & $41.5 \pm 0.3 \mathrm{~d}$ \\
\hline \multirow{3}{*}{$\begin{array}{l}\text { Spray of } \\
\text { potassium } \\
\text { iodide }\end{array}$} & 0.5 & $4.6 \pm 0.8 \mathrm{~b}$ & $7.6 \pm 3.5 \mathrm{~b}$ & $7.5 \pm 1.7 \mathrm{~b}$ & $10.1 \pm 1.7 \mathrm{~b}$ & $43.0 \pm 0.3 \mathrm{c}$ & $40.5 \pm 0.4 \mathrm{c}$ & $43.5 \pm 0.4 \mathrm{c}$ & $40.3 \pm 0.2 \mathrm{c}$ \\
\hline & 1.0 & $9.5 \pm 0.8 \mathrm{c}$ & $11.0 \pm 2.9 \mathrm{bc}$ & $10.9 \pm 0.6 \mathrm{c}$ & $13.1 \pm 2.5 \mathrm{bc}$ & $41.3 \pm 0.5 b$ & $39.0 \pm 0.1 \mathrm{~b}$ & $41.0 \pm 0.1 \mathrm{~b}$ & $38.9 \pm 0.3 b$ \\
\hline & 1.5 & $15.1 \pm 2.4 \mathrm{~d}$ & $18.3 \pm 2.5 \mathrm{~d}$ & $17.9 \pm 0.6 \mathrm{~d}$ & $25.4 \pm 3.7 \mathrm{~d}$ & $39.0 \pm 0.4 \mathrm{a}$ & $36.5 \pm 0.6 \mathrm{a}$ & $38.8 \pm 0.3 \mathrm{a}$ & $36.5 \pm 0.6 \mathrm{a}$ \\
\hline \multirow{3}{*}{$\begin{array}{l}\text { Spray of } \\
\text { potassium } \\
\text { iodate }\end{array}$} & 0.5 & $4.8 \pm 1.5 \mathrm{~b}$ & $9.5 \pm 0.6 \mathrm{~b}$ & $7.5 \pm 1.1 \mathrm{~b}$ & $8.3 \pm 2.6 \mathrm{~b}$ & $43.1 \pm 0.2 \mathrm{c}$ & $40.2 \pm 0.4 \mathrm{c}$ & $43.7 \pm 0.7 \mathrm{c}$ & $40.5 \pm 0.5 c$ \\
\hline & 1.0 & $9.2 \pm 1.3 \mathrm{c}$ & $12.3 \pm 0.3 \mathrm{c}$ & $10.1 \pm 0.4 \mathrm{c}$ & $16.5 \pm 1.5 \mathrm{c}$ & $41.2 \pm 0.4 b$ & $39.1 \pm 0.4 b$ & $40.3 \pm 0.4 b$ & $38.7 \pm 0.2 b$ \\
\hline & 1.5 & $16.5 \pm 1.2 \mathrm{~d}$ & $20.1 \pm 3.0 \mathrm{~d}$ & $19.3 \pm 1.1 \mathrm{~d}$ & $28.2 \pm 1.2 \mathrm{~d}$ & $39.1 \pm 0.8 \mathrm{a}$ & $35.9 \pm 0.3 \mathrm{a}$ & $39.1 \pm 0.2 \mathrm{a}$ & $36.1 \pm 0.4 \mathrm{a}$ \\
\hline Control & 0 & $0 \pm 0 \mathrm{a}$ & $0 \pm 0 \mathrm{a}$ & $0 \pm 0 \mathrm{a}$ & $0 \pm 0 \mathrm{a}$ & $42.7 \pm 0.6 \mathrm{c}$ & $41.6 \pm 0.1 \mathrm{~d}$ & $43.0 \pm 0.7 \mathrm{c}$ & $41.5 \pm 0.3 \mathrm{~d}$ \\
\hline
\end{tabular}

Means with the same letter within each column are not significantly different by Duncan's multiple range test at $\alpha=0.05$

*4 DAS $-4 \mathrm{~d}$ after the I spray

**3 WAH-3 weeks after harvest 
Table 4 Effects of different strategies of iodine (I) application on defoliation and cold damage of flower buds of 'Red Jonaprince' apple trees

\begin{tabular}{|c|c|c|c|c|c|c|c|c|c|}
\hline \multirow[t]{3}{*}{ Treatment } & \multirow{3}{*}{$\begin{array}{l}\text { I dose } \\
\left(\mathrm{kg} \mathrm{ha}^{-1}\right)\end{array}$} & \multicolumn{6}{|c|}{ Percentage of fallen leaves } & \multicolumn{2}{|c|}{ Cold bud damage (\%) } \\
\hline & & \multicolumn{2}{|l|}{2018} & \multirow[b]{2}{*}{ III term* } & \multicolumn{3}{|l|}{2019} & \multirow[t]{2}{*}{2019} & \multirow[t]{2}{*}{2020} \\
\hline & & I term* & II term* & & I term & II term & III term & & \\
\hline \multirow{3}{*}{$\begin{array}{l}\text { Soil applica- } \\
\text { tion of potas- } \\
\text { sium iodide }\end{array}$} & 4 & $6.1 \pm 2.1 \mathrm{a}$ & $35.4 \pm 9.2 \mathrm{a}$ & $60.2 \pm 4.2 \mathrm{a}$ & $7.5 \pm 0.7 \mathrm{a}$ & $35.5 \pm 3.5 \mathrm{a}$ & $72.4 \pm 6.4 \mathrm{a}$ & $3.1 \pm 0.5 \mathrm{a}$ & $4.4 \pm 0.6 \mathrm{a}$ \\
\hline & 8 & $7.3 \pm 0.8 \mathrm{a}$ & $32.1 \pm 8.5 \mathrm{a}$ & $62.3 \pm 3.5 \mathrm{a}$ & $7.7 \pm 0.8 \mathrm{a}$ & $36.1 \pm 3.5 \mathrm{a}$ & $70.1 \pm 8.8 \mathrm{a}$ & $2.6 \pm 0.5 \mathrm{a}$ & $3.5 \pm 0.5 \mathrm{a}$ \\
\hline & 12 & $7.0 \pm 0.5 \mathrm{a}$ & $35.0 \pm 4.9 \mathrm{a}$ & $66.3 \pm 5.1 \mathrm{a}$ & $6.6 \pm 0.3 \mathrm{a}$ & $37.5 \pm 7.8 \mathrm{a}$ & $75.3 \pm 4.1 \mathrm{a}$ & $3.0 \pm 0.4 \mathrm{a}$ & $3.9 \pm 0.8 \mathrm{a}$ \\
\hline \multirow{3}{*}{$\begin{array}{l}\text { Soil applica- } \\
\text { tion of potas- } \\
\text { sium iodate }\end{array}$} & 4 & $6.9 \pm 0.4 \mathrm{a}$ & $30.8 \pm 6.4 \mathrm{a}$ & $60.2 \pm 7.6 \mathrm{a}$ & $6.9 \pm 0.5 \mathrm{a}$ & $38.1 \pm 6.4 \mathrm{a}$ & $77.1 \pm 4.6 \mathrm{a}$ & $2.9 \pm 0.5 \mathrm{a}$ & $4.0 \pm 0.5 \mathrm{a}$ \\
\hline & 8 & $7.1 \pm 0.5 \mathrm{a}$ & $34.1 \pm 5.6 \mathrm{a}$ & $66.3 \pm 3.4 \mathrm{a}$ & $7.6 \pm 0.2 \mathrm{a}$ & $37.5 \pm 7.8 \mathrm{a}$ & $73.4 \pm 2.1 \mathrm{a}$ & $2.6 \pm 0.5 \mathrm{a}$ & $3.6 \pm 0.4 \mathrm{a}$ \\
\hline & 12 & $7.5 \pm 0.5 \mathrm{a}$ & $35.1 \pm 4.9 \mathrm{a}$ & $67.8 \pm 4.6 \mathrm{a}$ & $7.8 \pm 0.4 \mathrm{a}$ & $34.1 \pm 7.3 \mathrm{a}$ & $74.1 \pm 4.2 \mathrm{a}$ & $3.3 \pm 0.5 \mathrm{a}$ & $3.8 \pm 0.6 \mathrm{a}$ \\
\hline \multirow{3}{*}{$\begin{array}{l}\text { Spray of potas- } \\
\text { sium iodide }\end{array}$} & 0.5 & $8.5 \pm 2.3 \mathrm{a}$ & $38.1 \pm 8.5 \mathrm{a}$ & $66.8 \pm 4.7 \mathrm{a}$ & $7.8 \pm 0.5 \mathrm{a}$ & $37.4 \pm 7.8 \mathrm{a}$ & $76.2 \pm 5.1 \mathrm{a}$ & $3.2 \pm 0.4 \mathrm{a}$ & $4.1 \pm 0.4 \mathrm{a}$ \\
\hline & 1.0 & $15.6 \pm 2.5 b$ & $55.7 \pm 3.5 b$ & $76.8 \pm 2.1 \mathrm{~b}$ & $18.2 \pm 0.7 b$ & $65.1 \pm 8.8 b$ & $88.7 \pm 4.2 b$ & $3.1 \pm 0.2 \mathrm{a}$ & $4.2 \pm 0.3 \mathrm{a}$ \\
\hline & 1.5 & $17.2 \pm 2.0 \mathrm{~b}$ & $58.9 \pm 6.4 b$ & $77.9 \pm 2.1 b$ & $20.1 \pm 3.8 b$ & $68.9 \pm 3.5 b$ & $89.1 \pm 1.7 b$ & $2.6 \pm 0.4 \mathrm{a}$ & $3.9 \pm 0.5 \mathrm{a}$ \\
\hline \multirow{3}{*}{$\begin{array}{l}\text { Spray of potas- } \\
\text { sium iodate }\end{array}$} & 0.5 & $8.1 \pm 1.2 \mathrm{a}$ & $38.1 \pm 4.9 \mathrm{a}$ & $62.8 \pm 5.6 \mathrm{a}$ & $6.1 \pm 0.5 \mathrm{a}$ & $34.1 \pm 4.2 \mathrm{a}$ & $71.4 \pm 4.9 \mathrm{a}$ & $2.8 \pm 0.4 \mathrm{a}$ & $3.8 \pm 0.6 \mathrm{a}$ \\
\hline & 1.0 & $14.8 \pm 2.0 \mathrm{~b}$ & $59.0 \pm 8.4 b$ & $79.7 \pm 3.7 b$ & $15.7 \pm 2.3 b$ & $72.1 \pm 2.8 b$ & $87.4 \pm 4.7 b$ & $3.0 \pm 0.3 \mathrm{a}$ & $3.3 \pm 0.8 \mathrm{a}$ \\
\hline & 1.5 & $16.7 \pm 2.5 b$ & $60.1 \pm 6.4 b$ & $75.6 \pm 3.6 b$ & $19.9 \pm 2.3 b$ & $70.2 \pm 7.1 \mathrm{~b}$ & $88.1 \pm 5.4 b$ & $3.1 \pm 0.3 \mathrm{a}$ & $3.3 \pm 0.8 \mathrm{a}$ \\
\hline Control & 0 & $7.8 \pm 1.0 \mathrm{a}$ & $32.4 \pm 3.5 \mathrm{a}$ & $64.8 \pm 2.1 \mathrm{a}$ & $6.9 \pm 0.7 \mathrm{a}$ & $39.6 \pm 2.1 \mathrm{a}$ & $76.3 \pm 4.2 \mathrm{a}$ & $2.9 \pm 0.4 \mathrm{a}$ & $4.0 \pm 0.4 \mathrm{a}$ \\
\hline
\end{tabular}

Means with the same letter within each column are not significantly different by Duncan's multiple range test at $\alpha=0.05$

*I, II and III terms of defoliation were assessed when 5-10\% of leaves from the control trees fallen and 20 and $30 \mathrm{~d}$ later, respectively

Fruit quality

None of the I treatments affected the mean fruit weight (Table 6). Fruit skin russeting (mainly around the calyx) was slight and did not depend on the tested I treatments (Table 6).

Apple blushing was not affected by the I treatments, averaging 4.7 and 4.5 in 2018 and 2019,

Table 5 Effects of different strategies of iodine (I) application on vegetative and yield responses of 'Red Jonaprince' apple trees

\begin{tabular}{|c|c|c|c|c|c|c|c|}
\hline \multirow[t]{2}{*}{ Treatment } & \multirow[t]{2}{*}{$\begin{array}{l}\text { I dose } \\
\left(\mathrm{kg} \mathrm{ha}^{-1}\right)\end{array}$} & \multicolumn{2}{|c|}{ Mean leaf area $\left(\mathrm{cm}^{2}\right)$} & \multicolumn{2}{|c|}{$\begin{array}{l}\text { Total length of one-year- } \\
\text { old shoots per tree }(\mathrm{m})\end{array}$} & \multicolumn{2}{|c|}{ Fruit yield $\left(\mathrm{kg}\right.$ tree $\left.{ }^{-1}\right)$} \\
\hline & & 2018 & 2019 & 2018 & 2019 & 2018 & 2019 \\
\hline \multirow[t]{3}{*}{ Soil application of potassium iodide } & 4 & $27.8 \pm 0.3 \mathrm{a}$ & $27.3 \pm 0.5 \mathrm{a}$ & $11.7 \pm 1.5 \mathrm{a}$ & $13.2 \pm 0.5 \mathrm{a}$ & $23.3 \pm 1.8 \mathrm{a}$ & $18.9 \pm 1.5 \mathrm{a}$ \\
\hline & 8 & $27.2 \pm 0.8 \mathrm{a}$ & $27.9 \pm 1.0 \mathrm{a}$ & $12.2 \pm 1.3 \mathrm{a}$ & $12.8 \pm 0.3 \mathrm{a}$ & $22.8 \pm 1.7 \mathrm{a}$ & $19.3 \pm 1.4 \mathrm{a}$ \\
\hline & 12 & $27.5 \pm 0.3 \mathrm{a}$ & $27.9 \pm 0.5 \mathrm{a}$ & $11.9 \pm 0.8 \mathrm{a}$ & $13.3 \pm 0.7 \mathrm{a}$ & $23.1 \pm 1.5 \mathrm{a}$ & $19.1 \pm 1.4 \mathrm{a}$ \\
\hline \multirow[t]{3}{*}{ Soil application of potassium iodate } & 4 & $27.1 \pm 1.1 \mathrm{a}$ & $27.4 \pm 1.3 \mathrm{a}$ & $12.4 \pm 2.3 \mathrm{a}$ & $13.4 \pm 0.5 \mathrm{a}$ & $23.4 \pm 0.5 \mathrm{a}$ & $19.2 \pm 1.4 \mathrm{a}$ \\
\hline & 8 & $27.6 \pm 0.3 \mathrm{a}$ & $27.3 \pm 0.4 \mathrm{a}$ & $12.0 \pm 1.3 \mathrm{a}$ & $13.4 \pm 1.7 \mathrm{a}$ & $22.9 \pm 0.5 \mathrm{a}$ & $19.0 \pm 0.9 \mathrm{a}$ \\
\hline & 12 & $27.9 \pm 0.6 \mathrm{a}$ & $27.3 \pm 0.7 \mathrm{a}$ & $11.9 \pm 0.4 \mathrm{a}$ & $13.1 \pm 2.0 \mathrm{a}$ & $23.4 \pm 0.5 \mathrm{a}$ & $19.5 \pm 1.5 \mathrm{a}$ \\
\hline \multirow[t]{3}{*}{ Spray of potassium iodide } & 0.5 & $27.3 \pm 0.8 \mathrm{a}$ & $27.8 \pm 0.5 \mathrm{a}$ & $11.7 \pm 1.0 \mathrm{a}$ & $13.2 \pm 0.8 \mathrm{a}$ & $23.0 \pm 1.5 \mathrm{a}$ & $19.0 \pm 1.6 \mathrm{a}$ \\
\hline & 1.0 & $27.5 \pm 0.5 \mathrm{a}$ & $27.4 \pm 0.5 \mathrm{a}$ & $12.1 \pm 1.6 \mathrm{a}$ & $12.8 \pm 0.5 \mathrm{a}$ & $23.1 \pm 0.8 \mathrm{a}$ & $18.9 \pm 1.0 \mathrm{a}$ \\
\hline & 1.5 & $27.8 \pm 0.3 \mathrm{a}$ & $27.8 \pm 0.3 \mathrm{a}$ & $12.2 \pm 0.5 \mathrm{a}$ & $13.6 \pm 1.5 \mathrm{a}$ & $22.9 \pm 1.5 \mathrm{a}$ & $19.3 \pm 1.4 \mathrm{a}$ \\
\hline \multirow[t]{3}{*}{ Spray of potassium iodate } & 0.5 & $27.1 \pm 1.2 \mathrm{a}$ & $27.5 \pm 1.2 \mathrm{a}$ & $12.2 \pm 0.8 \mathrm{a}$ & $13.4 \pm 0.8 \mathrm{a}$ & $23.2 \pm 1.1 \mathrm{a}$ & $18.9 \pm 0.7 \mathrm{a}$ \\
\hline & 1.0 & $27.1 \pm 1.0 \mathrm{a}$ & $27.8 \pm 0.8 \mathrm{a}$ & $11.8 \pm 0.8 \mathrm{a}$ & $13.4 \pm 0.8 \mathrm{a}$ & $23.1 \pm 1.5 \mathrm{a}$ & $19.2 \pm 1.1 \mathrm{a}$ \\
\hline & 1.5 & $27.8 \pm 0.3 \mathrm{a}$ & $28.1 \pm 0.9 \mathrm{a}$ & $12.1 \pm 0.8 \mathrm{a}$ & $13.1 \pm 0.8 \mathrm{a}$ & $22.9 \pm 0.5 \mathrm{a}$ & $19.0 \pm 1.0 \mathrm{a}$ \\
\hline Control & 0 & $27.5 \pm 0.8 \mathrm{a}$ & $27.8 \pm 0.5 \mathrm{a}$ & $11.8 \pm 0.9 \mathrm{a}$ & $13.3 \pm 0.9 \mathrm{a}$ & $22.8 \pm 1.1 \mathrm{a}$ & $19.1 \pm 1.1 \mathrm{a}$ \\
\hline
\end{tabular}

Means with the same letter within each column are not significantly different by Duncan's multiple range test at $\alpha=0.05$ 
Table 6 Effects of different strategies of iodine (I) application on the selected external and internal quality parameters of 'Red Jonaprince' apples at harvest

\begin{tabular}{|c|c|c|c|c|c|c|c|c|c|}
\hline \multirow[t]{2}{*}{ Treatment } & \multirow[t]{2}{*}{$\begin{array}{l}\text { I dose } \\
\left(\mathrm{kg} \mathrm{ha}^{-1}\right)\end{array}$} & \multicolumn{2}{|c|}{ Mean fruit weight (g) } & \multicolumn{2}{|c|}{$\begin{array}{l}\text { Skin russeting } \\
(1-5)\end{array}$} & \multicolumn{2}{|c|}{$\begin{array}{l}\text { Soluble solid concentra- } \\
\text { tion }(\%)\end{array}$} & \multicolumn{2}{|l|}{ Acidity (\%) } \\
\hline & & 2018 & 2019 & 2018 & 2019 & 2018 & 2019 & 2018 & 2019 \\
\hline \multirow{3}{*}{$\begin{array}{l}\text { Soil appli- } \\
\text { cation of } \\
\text { potassium } \\
\text { iodide }\end{array}$} & 4 & $\pm 3.7 \mathrm{a}$ & $a$ & $\pm 0.3 \mathrm{a}$ & $\mathrm{a}$ & $3 b$ & $14.1 \pm 0.3 b$ & $0.86 \pm$ & $a$ \\
\hline & 8 & $168 \pm 7.0 \mathrm{a}$ & $181 \pm 8.5 \mathrm{a}$ & $1.8 \pm 0.3 \mathrm{a}$ & $1.3 \pm 0.2 \mathrm{a}$ & $13.6 \pm 0.2 b$ & $14.0 \pm 0.2 b$ & $0.83 \pm 0$ & $0.94 \pm 0.06 \mathrm{a}$ \\
\hline & 12 & $166 \pm 8.5 \mathrm{a}$ & $180 \pm 6.4 \mathrm{a}$ & $1.4 \pm 0.2 \mathrm{a}$ & $1.4 \pm 0.3 \mathrm{a}$ & $13.7 \pm 0.2 b$ & $14.2 \pm 0.2 b$ & $0.85 \pm 0.07 \mathrm{a}$ & $0.97 \pm 0.03 a$ \\
\hline \multirow{3}{*}{$\begin{array}{l}\text { Soil appli- } \\
\text { cation of } \\
\text { potassium } \\
\text { iodate }\end{array}$} & 4 & $166 \pm 3.4 \mathrm{a}$ & $181 \pm 8.5 \mathrm{a}$ & $1.3 \pm 0.2 \mathrm{a}$ & $1.3 \pm 0.2 \mathrm{a}$ & $13.7 \pm 0.2 b$ & $14.0 \pm 0.2 b$ & $0.87 \pm 0.08 \mathrm{a}$ & $0.97 \pm 0.06 \mathrm{a}$ \\
\hline & 8 & $167 \pm 7.8 \mathrm{a}$ & $183 \pm 5.7 \mathrm{a}$ & $1.4 \pm 0.3 \mathrm{a}$ & $1.6 \pm 0.4 \mathrm{a}$ & $13.9 \pm 0.3 b$ & $14.1 \pm 0.2 \mathrm{~b}$ & $0.86 \pm 0.04 \mathrm{a}$ & $0.96 \pm 0.03 \mathrm{a}$ \\
\hline & 12 & $\pm 3.4 \mathrm{a}$ & $3 a$ & $2 \mathrm{a}$ & $2 \mathrm{a}$ & 1 & & $2 \mathrm{a}$ & $05 \mathrm{a}$ \\
\hline \multirow{3}{*}{$\begin{array}{l}\text { Spray of } \\
\text { potassium } \\
\text { iodide }\end{array}$} & 0.5 & $168 \pm 7.8 \mathrm{a}$ & $183 \pm 4.3 \mathrm{a}$ & $1.5 \pm 0.3 \mathrm{a}$ & $1.4 \pm 0.4 \mathrm{a}$ & $13.9 \pm 0.3 b$ & $14.0 \pm 0.2 \mathrm{~b}$ & $0.83 \pm 0.06 \mathrm{a}$ & $0.95 \pm 0.03 \mathrm{a}$ \\
\hline & 1.0 & $163 \pm 3.5 \mathrm{a}$ & $185 \pm 4.5 \mathrm{a}$ & $1.6 \pm 0.5 \mathrm{a}$ & $1.5 \pm 0.3 \mathrm{a}$ & $13.8 \pm 0.4 b$ & $13.9 \pm 0.2 b$ & $0.85 \pm 0.06 \mathrm{a}$ & $0.98 \pm 0.11 \mathrm{a}$ \\
\hline & 1. & $165 \pm 3.5 \mathrm{a}$ & $180 \pm 4.9 \mathrm{a}$ & $1.5 \pm 0.3 \mathrm{a}$ & $1.3 \pm 0.2 \mathrm{a}$ & $12.8 \pm 0.2 \mathrm{a}$ & $13.1 \pm 0.2 \mathrm{a}$ & $0.86 \pm 0.02 \mathrm{a}$ & $0.96 \pm 0.03 \mathrm{a}$ \\
\hline \multirow{3}{*}{$\begin{array}{l}\text { Spray of } \\
\text { potassium } \\
\text { iodate }\end{array}$} & 0.5 & $166 \pm 7.8 \mathrm{a}$ & $184 \pm 5.6 \mathrm{a}$ & $1.2 \pm 0.2 \mathrm{a}$ & $1.3 \pm 0.2 \mathrm{a}$ & $13.7 \pm 0.2 b$ & $14.1 \pm 0.3 b$ & $0.85 \pm 0.06 \mathrm{a}$ & $0.99 \pm 0.09 a$ \\
\hline & 1.0 & $165 \pm 5.8 \mathrm{a}$ & $183 \pm 3.4 \mathrm{a}$ & $1.5 \pm 0.4 \mathrm{a}$ & $1.5 \pm 0.3 \mathrm{a}$ & $13.9 \pm 0.3 b$ & $13.9 \pm 0.2 b$ & $0.85 \pm 0.06 \mathrm{a}$ & $0.95 \pm 0.04 \mathrm{a}$ \\
\hline & 1.5 & $168 \pm 4.2 \mathrm{a}$ & $183 \pm 4.2 \mathrm{a}$ & $1.4 \pm 0.3 \mathrm{a}$ & $1.6 \pm 0.4 \mathrm{a}$ & $12.8 \pm 0.3 \mathrm{a}$ & $13.2 \pm 0.3 \mathrm{a}$ & $0.82 \pm 0.04 \mathrm{a}$ & $0.98 \pm 0.02 \mathrm{a}$ \\
\hline Control & 0 & $166 \pm 6.2 \mathrm{a}$ & $180 \pm 6.4 \mathrm{a}$ & $1.4 \pm 0.3 \mathrm{a}$ & $1.2 \pm 0.1 \mathrm{a}$ & $13.9 \pm 0.3 b$ & $14.2 \pm 0.4 \mathrm{~b}$ & $0.83 \pm 0.03 \mathrm{a}$ & $0.94 \pm 0.03 a$ \\
\hline
\end{tabular}

Means with the same letter within each column are not significantly different by Duncan's multiple range test at $\alpha=0.05$

respectively (Table S1). Flesh firmness and the content of organic acids in fruit did not differ between the combinations (Table S1). However, regardless of the I species used, apples sprayed with this nutrient at a rate of $1.5 \mathrm{~kg} \mathrm{ha}^{-1}$ had lower SSC than those of other combinations (Table 6). Apple SI values were comparable between the combinations, averaging 6.2 in 2018 and 6.8 in 2019 (Table S1).

\section{Discussion}

Soil I and absorption of I by trees

After two cropping seasons, the total soil I concentrations on all plots were within the natural range of $0.8-10 \mathrm{mg} \mathrm{kg}^{-1}$ given by Kabata-Pendias and Pendias (1999) for the surface soil layer in Poland. A similar soil I range has been found by Schnell and Aumann (1999) in Germany (0.4-6.5 mg kg-1). According to Whitehead (1984) typical I concentrations in soils worldwide vary from $0.5 \mathrm{mg}$ to $20 \mathrm{mg} \mathrm{kg}^{-1}$.

The share of water-soluble I to its total concentration in soil varied from $5.3 \%$ to $8.1 \%$ (Table 1), which is a similar range to that found by Schmitz and Aumann (1994) in mineral soils in Germany
(2.5-9.7\%). In addition, studies in the United Kingdom (in Wales) and Morocco (in the High Atlas Mountain area) revealed that up to $10 \%$ of total soil I was water soluble (Johnson 1980; Johnson et al. 2002).

In our study, I loss from the top soil of the control plot during period of two cropping seasons was only $0.01 \mathrm{mg} \mathrm{I} \mathrm{kg}^{-1}$ (corresponding to $48 \mathrm{~g} \mathrm{I} \mathrm{ha}^{-1}$ ), whereas the amount of I removed from fruit yields was $1.94 \mathrm{~g} \mathrm{ha}^{-1}$ (Table S2). In addition, for two growing seasons the amount of I taken up by leaves of the control trees was $0.59 \mathrm{~g} \mathrm{ha}^{-1}$ [assuming that the total DW of leaves per ha is $1195.5 \mathrm{~kg}$, as has been calculated by Buler (2003) for 6-year-old 'Šampion' apple trees planted at a density of 1904 trees ha ${ }^{-1}$ ]. Taken together, our quantitative analyses clearly indicate that in two consecutive cropping seasons, the amount of I taken up by control apple trees was a much lower (ca. $2.5 \mathrm{~g} \mathrm{ha}^{-1}$ ) than the calculated I loss from the top soil, indicating that a significant portion of the endogenous I was leached down the soil profile or was taken up by roots and woody parts of the trees.

In the present study, In the present study, the loss of the applied I from the top soil in the two growing seasons were $+1.10 \mathrm{~kg} \mathrm{KI}-\mathrm{I} \mathrm{ha}{ }^{-1}$ versus $+1.10 \mathrm{~kg}$ $\mathrm{KIO}_{3}-\mathrm{I} \mathrm{ha}{ }^{-1}$ for the rate of $4 \mathrm{~kg} \mathrm{I} \mathrm{ha}{ }^{-1},+4.61 \mathrm{~kg} \mathrm{KI}-\mathrm{I}$ 
$\mathrm{ha}^{-1}$ versus $+0.29 \mathrm{~kg} \mathrm{KIO}_{3}-\mathrm{I} \mathrm{ha}^{-1}$ for the rate of $8 \mathrm{~kg}$ $\mathrm{I} \mathrm{ha}^{-1}$ and $+9.07 \mathrm{~kg} \mathrm{KI}-\mathrm{I} \mathrm{ha}^{-1}$ versus $-0.53 \mathrm{~kg} \mathrm{KIO}_{3}-\mathrm{I}$ $\mathrm{ha}^{-1}$ for the rate of $12 \mathrm{~kg} \mathrm{ha}^{-1}$. Those data indicate that retention rates of $\mathrm{IO}_{3}^{-}$at higher I doses $(8 \mathrm{~kg}$ and $12 \mathrm{~kg} \mathrm{ha}^{-1}$ ) were considerably greater than those with use of $\mathrm{I}^{-}$. This finding is in agreement with a previous report showing less mobility of $\mathrm{IO}_{3}{ }^{-}$compared with $\mathrm{I}^{-}$in different types of mineral soils (Hong et al. 2012). Although the mechanisms underlying the observed differences in soil retention rates between $\mathrm{IO}_{3}{ }^{-}$and $\mathrm{I}^{-}$forms have not yet been defined completely defined so far, a preferential adsorption of $\mathrm{IO}_{3}{ }^{-}$on the hydrous $\mathrm{Fe} / \mathrm{Al} / \mathrm{Mn}$ oxides has been recognised (Kodama et al. 2006; Shetaya et al. 2012). The higher affinity of the metal oxides for $\mathrm{IO}_{3}{ }^{-}$is attributed to chemical bonding of ions to oxide surfaces through replacement of hydroxyl groups (Fukui et al. 1996; Um et al. 2004).

Given the aforementioned information, it should also be noted that when $12 \mathrm{~kg} \mathrm{IO}_{3}^{-}-\mathrm{I} \mathrm{ha}^{-1}$ was applied, the amount of I at the top soil was higher by $0.53 \mathrm{~kg} \mathrm{ha}^{-1}$ than expected based on the rate used. This issue can be, at least partially, explained by the fact that soil was enriched with I from fallen unfertilised flowers, fruitlets and leaves. In addition, we cannot exclude the possibility that significant sources of I such as irrigation water and mown grass displaced from alleyways by an orchard mower may have enriched the soil within the herbicide strips along tree rows. Unfortunately, in our study I concentrations in irrigation water and grass-forming sward in the interrows were not determined.

Based on I contents in the given parts of apple trees (Table S2), we can conclude that in the two growing seasons, the I absorption rates by soil-I-supplied trees were: $3.47 \mathrm{~g} \mathrm{KI}-\mathrm{I} \mathrm{ha}^{-1}$ versus $3.26 \mathrm{~g} \mathrm{KIO}_{3}-\mathrm{I} \mathrm{ha}^{-1}$ for the rate of $4 \mathrm{~kg} \mathrm{I} \mathrm{ha}^{-1}, 5.53 \mathrm{~g} \mathrm{KI}^{\mathrm{I}} \mathrm{ha}^{-1}$ versus $5.51 \mathrm{~g}$ $\mathrm{KIO}_{3}-\mathrm{I} \mathrm{ha}^{-1}$ for the rate of $8 \mathrm{~kg} \mathrm{I} \mathrm{ha}^{-1}$ and $9.48 \mathrm{~g} \mathrm{KI}-\mathrm{I}$ $\mathrm{ha}^{-1}$ versus $9.45 \mathrm{~g} \mathrm{KIO}_{3}-\mathrm{I} \mathrm{ha}^{-1}$ for the rate of $12 \mathrm{~kg}$ $\mathrm{I} \mathrm{ha}^{-1}$. These data indicate that uptake rate of I by apple trees depended mainly on the dose used.

Taking into account the calculated I loss from the top soil for the given combinations, the shares of uptake rates of I by leaves and fruit in this process were $0.32 \%, 0.12 \%$, and $0.10 \%$ for $\mathrm{KI}$ and $0.30 \%, 1.9 \%$ and $0 \%$ for $\mathrm{KIO}_{3}$ in case of the use of $4 \mathrm{~kg}, 8 \mathrm{~kg}$ and $12 \mathrm{~kg} \mathrm{I}$ $\mathrm{ha}^{-1}$, respectively. These data indicate a low efficiency of absorption of exogenous I by apple trees.
Tree responses to soil I treatments

The I rates applied to the soil in our study can be considered moderate $\left(4 \mathrm{~kg} \mathrm{ha}^{-1}\right)$ or high $(8 \mathrm{~kg}$ and $12 \mathrm{~kg} \mathrm{ha}^{-1}$ ), taking into account doses of this nutrient that have been used in open field experiments in the growing of some fruit crops (Gonzali et al. 2017). For example, in the study by Caffagini et al. (2012) on plum and nectarine trees, the maximum I rate was $250 \mathrm{~g} \mathrm{ha}^{-1}$. Considerably greater I rates have been applied by Budke et al. (2020b) in strawberries (1-7.5 kg I ha ${ }^{-1}$ ).

Despite I application up to $12 \mathrm{~kg} \mathrm{ha}^{-1}$, no leaf toxicity symptoms were observed (Table 3 ). Apple leaf I toxicity, manifested as necrosis at the leaf tips and margins, was observed by Budke et al. (2020a) in a pot experiment. In that study, leaf I toxicity was recorded when its concentrations increased up to $109 \mathrm{mg} \mathrm{kg}^{-1} \mathrm{DW}$ [the value converted from $\mathrm{FW}$, assuming that the DW of apple leaves is $11 \%$ in $\mathrm{FW}$, as has been shown by Wójcik (1999)]. In the present experiment, the highest leaf I concentration on soilsupplied plots with this nutrient was found in 2018, using KI at a rate of $12 \mathrm{~kg} \mathrm{I} \mathrm{ha}^{-1}\left(0.791 \mathrm{mg} \mathrm{I} \mathrm{kg}^{-1}\right.$ DW). The lack of leaf injuries following I application probably resulted from a low efficiency of I absorption by roots and/or restricted movement into the above-ground tree parts. This appears to be true because the leaf I concentration of trees grown in soil supplied with this nutrient increased a maximum of threefold, while in the study by Budke et al. (2020a), for apple trees grown in I-enriched substrate, the leaf I concentrations were elevated up to 15 fold.

In several field experiments, soil application of both $\mathrm{IO}_{3}{ }^{-}$and $\mathrm{I}^{-}$improved efficiently the plant I status (Altinok et al. 2003; Cakmak et al. 2017; Hong et al. 2008 ; Lawson et al. 2015; Ledwozyw-Smolen et al. 2020; Mao et al. 2014; Smolen et al. 2011; Weng et al. 2013). Muramatsu et al. (1983) showed in a culture solution that komatsuna (Brassica Rapa var. pervidis) supplied with $\mathrm{IO}_{3}{ }^{-}$contained $\mathrm{I}$ in roots as $\mathrm{I}^{-}$, which, according to those authors, indicates that $\mathrm{IO}_{3}{ }^{-}$ions were reduced to $\mathrm{I}^{-}$before passing through the plasma membrane of epidermal root cells. The ability of roots to reduce $\mathrm{IO}_{3}^{-}$to $\mathrm{I}^{-}$has also been proven by Kato et al. (2013) for rice, barley and soybeans. Amachi (2008) found that the reduction process of $\mathrm{IO}_{3}{ }^{-}$to $\mathrm{I}^{-}$can be carried out not only by plant roots but also by 
microorganisms. According to Lawson et al. (2015), $\mathrm{IO}_{3}{ }^{-}$applied exogenously to soil is more efficiently taken up by roots than $\mathrm{I}^{-}$because it is less prone to leaching down the soil profile and volatilisation. Taking into account that in our study leaves, edible fruit parts and seeds from trees supplied with $\mathrm{IO}_{3}^{-}$and $\mathrm{I}^{-}$contained comparable I concentrations for a given rate of this nutrient (Table 2), we can state that the efficiency of the tested soil treatments in improving I uptake by trees was not affected by the I form used.

Tree responses to the I spray treatments

Under some conditions, foliar nutrient sprays, especially of trace elements, are believed to be an alternative to soil fertilisation (Eichert and Fernández 2012). Oestling et al. (1989) showed that leaves of beans (Vicia faba L.), potatoes and radishes were able to take up radioiodine. Later, it was shown that foliarapplied $\mathrm{I}_{\text {as I}} \mathrm{I}^{-}$or $\mathrm{IO}_{3}{ }^{-}$efficiently increased the I concentrations in plant tissues of some species (Altinok et al. 2003; Caffagni et al. 2012; Cakmak et al. 2017; Golob et al. 2020; Landini et al. 2011; Lawson et al. 2015; Smolen et al. 2014; Ledwozyw-Smolen et al. 2020).

In the study by Budke et al. (2020a) carried out under a plastic tunnel KI spray at a rate of $0.75 \mathrm{~g} \mathrm{I}$ $\mathrm{L}^{-1}$ water (using about $100 \mathrm{ml}$ the solution per tree) caused 'Golden Delicious' apple leaf burns on up to one third of leaf area. In 'Jonagold' apple orchard sprayed with $\mathrm{KI}$ or $\mathrm{KIO}_{3} 2$ weeks before harvest at rates of $0.25-2.5 \mathrm{~kg} \mathrm{I}(\mathrm{ha} \cdot \mathrm{m} \mathrm{CH})^{-1}$ caused leaf injury in the range of 3.0-5.7 for $\mathrm{KI}$ and 2.4-6.7 for $\mathrm{KIO}_{3}$ according to a 9-point scale, where 1 means no leaf damage and 9 very severe leaf damage. In our study, the KI spray at lowest rate of $1 \mathrm{~g} \mathrm{I} \mathrm{L}^{-1}$ water $[0.21 \mathrm{~kg}$ $\mathrm{I}$ (ha $\cdot \mathrm{m} \mathrm{CH})^{-1}$ ] injured only approximately $10 \%$ of the leaf blade area. Moreover, the maximum KI rate of $3 \mathrm{~g} \mathrm{I} \mathrm{L}^{-1}$ water [0.63 $\mathrm{kg} \mathrm{I}(\mathrm{ha} \cdot \mathrm{m} \mathrm{CH})^{-1}$ ] caused leaf damage to $25 \%$ of the leaf area (Table 3 ). Considerable differences in the susceptibility of apple leaves to burns as a result of the sprays recorded by Budke et al. (2020a, 2021) and in the present experiment could result from different tree growth conditions (such as air temperature, humidity, rainfall and light intensity), tree growth stage and the I rates used as has been reported by Świetlik and Faust (1984). It is worth noting that in our experiment, damage of leaves was not affected by the I form even though the spray solution I concentrations containing $\mathrm{KIO}_{3}$ were $31 \%$ higher compared with those with the use of KI. Similarly, Budke et al. (2021) showed no significant difference in apple leaf damage between sprays of KI and $\mathrm{KIO}_{3}$.

In the present study, except for the I sprays at the lowest rate, other spray treatments decreased leaf SPAD readings (Table 3 ). The drops obtained in SPAD readings (from 43.0 to 39.0 for 4 DAS and from 41.8 to 35.9 for $3 \mathrm{WAH}$ ) were analogous to those found in the study by Wójcik (2001) in which fall sprays of Ca-chloride at high rates caused 'Jonagold' apple leaf burns and, consequently, the reduction of leaf chlorophyll content. The lack of effects of the I sprays at the lowest rate on leaf SPAD readings was related to the fact that the leaf burn area was only $10 \%$ and was located mainly at the blade tips and margins, while leaf SPAD readings were made at the halfway point between the tip and base, $1 \mathrm{~cm}$ from the blade edge.

Leaf injury and defoliation of perennial crops may lead to bud weakness and, consequently, decrease their cold hardiness. This relationship results from limited supply of assimilates from leaves to buds (Jackson 2003). In the present study, despite the leaf injury that occurred with all I spray treatments and defoliation from those trees (except for I-sprayed trees at the lowest rate), we did not find an impact of the I sprays on cold bud damage (Table 4). This is not surprising because in our study the beginning of defoliation was late autumn (in the first and second decade of November of 2018 and 2019, respectively), which could not affect the cold hardiness of the above-ground parts of trees. According to Czynczyk et al. (2004), under Polish conditions, there is a decrease in the winter hardiness of mature apple trees as a result of defoliation when it takes place before mid-September. It should also be noted that the lowest air temperatures in the region of the experiment were $-12{ }^{\circ} \mathrm{C}$ in the winter of 2018/2019 (on 1 December) and $-10{ }^{\circ} \mathrm{C}$ in the winter of $2019 / 2020$ (on 24 March). These minimum temperatures are considerably higher than the critical temperatures during the winter dormancy period for mature apple tree varieties grown in Poland $\left(<-20^{\circ} \mathrm{C}\right)$ given by Czynczyk et al. (2004).

Taking into account that the total length of 1-year-old shoots per tree and leaf size were comparable between all combinations (Table 5), we can conclude that the vigour/growth of apple trees was not affected by the I spray treatments. This conclusion concerns tree growth 
response to the I spray treatments during the year of their applications as well as subsequent effect in the year 2019. Lack of vegetative response of the trees to the I sprays is not surprising because these treatments were applied after growth of both current-season shoots and leaves ceased.

In the present study, I absorption rates by leaves from the KI sprays at rates of $1 \mathrm{~kg}$ and $1.5 \mathrm{~kg} \mathrm{I} \mathrm{ha}^{-1}$ were higher than those with the use of $\mathrm{KIO}_{3}$ at the corresponding doses (Table 2). Differences in I uptake by leaves from $\mathrm{KIO}_{3}$ and $\mathrm{KI}$ solutions can be attributed to the chemical properties of the salts used. Firstly, $\mathrm{KIO}_{3}$ is characterised by a high point of deliquescence (POD), defined as the relative humidity $(\mathrm{RH})$ at a given temperature at which the liquefaction of a salt into a solute takes place (Schönherr 2001). At $20{ }^{\circ} \mathrm{C}$, the POD value is $93.8 \%$ and $68.9 \%$ for $\mathrm{KIO}_{3}$ and KI, respectively (Apelblat and Korin 1998; Greenspan 1977). If the RH is below the POD value for salt, it will crystalise on the leaf surface. In Central Poland, where this study was carried out, an RH as high as the POD value for $\mathrm{KIO}_{3}$ does not occur frequently in the summer and early autumn. In our study, the I sprays were carried out when RH was $69 \%$ in 2018 and $72 \%$ in 2019, which did not favour I absorption by $\mathrm{KIO}_{3}$-sprayed leaves, at least immediately after spraying. Secondly, in contrast to $\mathrm{I}^{-}, \mathrm{IO}_{3}{ }^{-}$ion is a polyatomic and may slow down the diffusion rate from the cuticle to the epidermal cells (Eichert and Fernandez 2012).

In our experiment, none of the I spray treatments caused apple skin russeting despite recorded leaf burns (Tables 3,6). Budke et al. (2020a, 2021) also did not find the deterioration of apple appearance (including skin russeting) as a result of preharvest I sprays even when leaves were damaged. Wójcik (2001) and Wójcik et al. (2009), using high Ca rates in fall sprays, did not observe increased apple peel russeting, although the sprays caused leaf burns. This indicates that lenticels and the cuticle on the apple skin surface are more resistant to concentrated spray solutions (at least during period of apple ripening) than stomata and the apple leaf cuticle. This conclusion is in line with the opinion by Faust and Shear (1972) and Khanal et al. (2013).

Among the studied quality trials of apples, only SSC was decreased as a result of the I sprays at the highest rate (Table 6). Given that the SI in fruit flesh did not differ between the combinations (Table S1), we suggest that the decreased SSC in fruit resulted from the restricted production rate of carbohydrates in leaves and/or their transport into apples. This seems to be true, because the above-mentioned spray treatments caused strong leaf damage (up to $28 \%$ of the total leaf blade area).

\section{Fruit I}

The recommended daily intake of I for adolescents and adults is 150-200 $\mu \mathrm{g}$ (Zimmermann et al. 2008). According to Budke et al. (2020a, 2021) the targeted apple I range should be between $50 \mu \mathrm{g}$ and $100 \mu \mathrm{g} 100 \mathrm{~g}^{-1} \mathrm{FW}$. This range was estimated taking into account the fact that a considerable part of the I requirement is met by other sources in the diet (such as milk, fish, drinking water and iodised table salt) and that an individual apple usually weighs $150-200 \mathrm{~g}$.

In our study, I concentrations in the control apples were comparable to those found by Budke et al. (2021) in the native 'Jonagold' apple fruit $\left(1.5 \mu \mathrm{g} 100 \mathrm{~g}^{-1} \mathrm{FW}\right)$ in an orchard established on medium-textured soil. Regardless of this fact, apple I concentrations from the control trees were much lower than the targeted range recommended by Budke et al. (2020a, 2021).

It is noteworthy that only in the first year of the study the soil I treatments were able to increase I concentrations in edible fruit parts and seeds despite increased I concentrations in leaves in both growing seasons (Table 2). This suggests that I absorbed by apple tree roots was transported preferentially into leaves, and its redistribution (retranslocation) from woody into fruit tissues was restricted. The above suggestion is consistent with the results of a study by Budke et al. (2020a), who provided evidence of limited phloem I mobility within apple tree.

In our trial, the maximum apple I concentration was only $12.9 \mu \mathrm{g} 100 \mathrm{~g}^{-1} \mathrm{FW}$ when I was applied to the soil (Table 2). Therefore, apples from the trees supplied with I via the soil cannot be considered as a sufficiently rich I source, at least under conditions of medium-textured soil with a moderate status of organic matter. 
In the literature, there are some studies on the effect of foliar I sprays on fruit I enrichment of perennial plants. For example, Caffagni et al. (2012), working with plums and nectarines, demonstrated that preharvest KI sprays at total rate of approximately $0.3 \mathrm{~kg} \mathrm{I} \mathrm{ha}^{-1}$ increased fruit I concentrations to $9.5 \mu \mathrm{g} 100 \mathrm{~g}^{-1} \mathrm{FW}$ and $14.3 \mu \mathrm{g} 100 \mathrm{~g}^{-1} \mathrm{FW}$, respectively. In strawberries, four sprays over the entire flowering period at total rate of $0.8 \mathrm{~kg} \mathrm{I} \mathrm{ha}^{-1}$ increased fruit I concentration to $57 \mu \mathrm{g} 100 \mathrm{~g}^{-1} \mathrm{FW}$, whereas a single KI spray before the first picking at rate of $0.2 \mathrm{~kg} \mathrm{I} \mathrm{ha}^{-1}$ enhanced fruit I to $46 \mu \mathrm{g}$ $100 \mathrm{~g}^{-1}$ FW (Budke et al. 2020b). Regarding apple trees grown under a plastic tunnel, two KI sprays at total rate of $1.5 \mathrm{~g} \mathrm{I} \mathrm{L}^{-1}$ water were reported to improve the I concentration in apples (skin and flesh tissues) to approximately $50 \mu \mathrm{g} 100 \mathrm{~g}^{-1} \mathrm{FW}$ (Budke et al. 2020a). In another study, carried out in a 'Jonagold' apple orchard, a single I spray of $0.25-2.5 \mathrm{~kg}$ (ha $\cdot \mathrm{m} \mathrm{CH}^{-1}$ applied 2 weeks before harvest was able to increase apple I concentrations from $15.7 \mu \mathrm{g}$ $100 \mathrm{~g}^{-1} \mathrm{FW}$ up to about $200 \mu \mathrm{g} 100 \mathrm{~g}^{-1} \mathrm{FW}$ (Budke et al. 2021). In our study, the KI spray at the highest rate $\left[1.5 \mathrm{~kg} \mathrm{I} \mathrm{ha}^{-1}\right.$ which corresponds to $0.63 \mathrm{~kg}$ I (ha $\cdot \mathrm{m} \mathrm{CH}^{-1}$ ] increased apple I concentrations to $231.6 \mu \mathrm{g} 100 \mathrm{~g}^{-1} \mathrm{FW}$ (Table 2). However, the above spray treatment decreased SSC in apples in both years (Table 6). The sprays of $\mathrm{KI}$ and $\mathrm{KIO}_{3}$ at rates of $0.5 \mathrm{~kg}$ and $1 \mathrm{~kg} \mathrm{I} \mathrm{ha}{ }^{-1}$ [corresponding to $0.21 \mathrm{~kg}$ and $0.42 \mathrm{~kg} \mathrm{I}$ (ha $\cdot \mathrm{m} \mathrm{CH})^{-1}$, respectively] also improved efficiently apple I concentrations (up to $94.1 \mu \mathrm{g}$ and $158.5 \mu \mathrm{g} 100 \mathrm{~g}^{-1} \mathrm{FW}$ for $\mathrm{KI}$ and $88.4 \mu \mathrm{g}$ and $95.7 \mu \mathrm{g} 100 \mathrm{~g}^{-1} \mathrm{FW}$ for $\mathrm{KIO}_{3}$, respectively) and importantly, they did not affect SSC in fruit. Thus, the above apple I concentrations were within the targeted range recommended by Budke et al. (2020a, 2021), or it was considerably higher when the KI spray was applied at a rate of $1 \mathrm{~kg} \mathrm{ha}^{-1}$ ).

It should be highlighted that in our study, the $\mathrm{KIO}_{3}$ sprays were less effective than the KI sprays in improving the apple I concentration (Table 2). Similar differences between the above I species were found by Budke et al. (2021) for sprays applied 2 weeks before harvest in 'Jonagold' apple orchard. The possible reasons for the reduced I absorption by apples from sprays of $\mathrm{KIO}_{3}$ were described in the part concerning I uptake by leaves from the tested spray treatments.

\section{Conclusions}

The results obtained from the study revealed that under conditions of sandy loam soil with moderate organic matter, the soil treatments of $\mathrm{KI}$ or $\mathrm{KIO}_{3}$ at rates from 4 to $12 \mathrm{~kg} \mathrm{I} \mathrm{ha}^{-1}$ were not highly efficient in increasing I concentrations of 'Red Jonaprince' apple trees. The sprays of $\mathrm{KI}$ or $\mathrm{KIO}_{3}$, applied 2 weeks before harvest at rates from $0.5 \mathrm{~kg}$ to $1.5 \mathrm{~kg}$ $\mathrm{I} \mathrm{ha}^{-1}$, resulted in leaf burns and defoliation (except for I use at $0.5 \mathrm{~kg} \mathrm{ha}^{-1}$ ) but did not affect tree growth, yield or apple appearance. The KI sprays at rates of $1 \mathrm{~kg}$ and $1.5 \mathrm{~kg} \mathrm{I} \mathrm{ha}^{-1}$ were more efficient than those with the use of $\mathrm{KIO}_{3}$ in improving I concentrations in leaves and edible apple parts. The highest I concentration in edible fruit parts, exceeding the daily recommended I intake for adults, occurred for the KI spray at the highest rate, although this treatment lowered SSC in fruit. The sprays of $\mathrm{KI}$ or $\mathrm{KIO}_{3}$ at doses of $0.5 \mathrm{~kg}$ and $1 \mathrm{~kg} \mathrm{I} \mathrm{ha}{ }^{-1}$ did not affect SSC in fruit and simultaneously were able to increase I concentrations in edible fruit parts to the targeted range (50-100 $\mu \mathrm{g}$ $100 \mathrm{~g}^{-1} \mathrm{FW}$ ) or above $150 \mu \mathrm{g}$ I as a daily requirement for this nutrient for the adults (in the case of the KI spray at rate of $1 \mathrm{~kg} \mathrm{ha}^{-1}$ ). For economic reasons, we conclude that the spray of $\mathrm{KI}$ or $\mathrm{KIO}_{3}$, applied 2 weeks before harvest at rate of $0.5 \mathrm{~kg} \mathrm{I} \mathrm{ha}^{-1}$, should be recommended in apple orchards to improve effectively the fruit I status, at least for mid- and late-season varieties grown in temperate climate. The choice of which food grade salt to use will depend mainly on the cost differences between $\mathrm{KI}$ and $\mathrm{KIO}_{3}$. On the Polish fertiliser market, prices of food-grade quality $\mathrm{KIO}_{3}$ and $\mathrm{KI}$ are $45 \mathrm{USD}$ and $70 \mathrm{USD} \mathrm{kg}{ }^{-1}$, respectively. Thus, although in the applied I sprays, $\mathrm{KIO}_{3}$ doses were higher than KI (by 30\%), the cost of use of $\mathrm{KIO}_{3}$ was lower by approximately $20 \%$ compared to $\mathrm{KI}$. In this context, $\mathrm{KIO}_{3}$ can be considered as the favoured foliar fertiliser.

Acknowledgements We would like to thank the fruit grower for carrying out the experiment and for supporting its realisation.

Authors contribution Conceptualization: Wójcik Paweł, Methodology: Wójcik Paweł, Formal analysis and investigation, Wójcik Paweł, Resources Wójcik Paweł, Wójcik Marzena, Visualization: Wójcik Paweł, Writing-original draft: Wójcik Paweł, Wójcik Marzena, Writing - review and ending. 


\section{Declaration}

Conflict of interest The authors declare that they have no known competing financial interests or personal relationships that could have appeared to influence the work reported in this paper.The authors declare the following financial interests/personal relationships which may be considered as potential competing interests.

Open Access This article is licensed under a Creative Commons Attribution 4.0 International License, which permits use, sharing, adaptation, distribution and reproduction in any medium or format, as long as you give appropriate credit to the original author(s) and the source, provide a link to the Creative Commons licence, and indicate if changes were made. The images or other third party material in this article are included in the article's Creative Commons licence, unless indicated otherwise in a credit line to the material. If material is not included in the article's Creative Commons licence and your intended use is not permitted by statutory regulation or exceeds the permitted use, you will need to obtain permission directly from the copyright holder. To view a copy of this licence, visit http://creativecommons.org/licenses/by/4.0/.

\section{References}

Allison LE (1965) Organic carbon. In: Black DD, Evans JL, White IE, Engminger IE, Clark FE (eds) Methods of soil analysis. American Society of Agronomy, Madison, pp $1367-1378$

Altinok S, Sozudogru-Ok S, Halilova H (2003) Effect of iodine treatments on forage yields of alfalfa. Commun Soil Sci Plant Anal 34:55-64. https://doi.org/10.1081/CSS-120017415

Amachi S (2008) Microbial contribution to global iodine cycling: volatilization, accumulation, reduction, oxidation, and sorption of iodine. Microbes Environ 23:269-276. https://doi.org/10.1264/jsme2.ME08548

Anderson M, Takkouche B, Egli I, Allen HE, de Benoist B (2005) Current global iodine status and progress over the last decade towards the elimination of iodine deficiency. Bull World Health Organ 83:518-525

Apelblat A, Korin E (1998) The vapour pressures of saturated aqueous solutions sodium chloride, sodium bromide, sodium nitrate, sodium nitrite, potassium iodate, and rubidium chloride at temperatures from $227 \mathrm{~K}$ to $323 \mathrm{~K}$. J Chem Thermodyn. 30:59-71.https://doi.org/10.10006/ jcht.1997.0275

Arthur JR, Beckett GJ (1999) Thyroid function. Br Med Bull 55:658-668. https://doi.org/10.1258/0007142991902538

Boyer J, Liu RH (2004) Apple phytochemicals and their health benefits. Nutr J. 3: 5. https://doi.org/10.1186/1475-2891-3-5

Budke C, Dierend W, Schön HG, Hora K, Mühling KH, Daum D (2021) Iodine biofortification of apples and pears in an orchard using foliar sprays of different composition. Front Plant Sci 12:638671. https://doi.org/10.3389/fpls.2021. 638671

Budke C, Mühling KH, Daum D (2020) Iodine uptake and translocation in apple trees grown under protected cultivation. J Plant Nutr Soil Sci 183:468-481. https://doi. org/10.1002/jpln.202000099

Budke C, thor Straten S, Mühling KH, Broll G, Daum D, (2020) Iodine biofortification of field-grown strawberries Approaches and their limitations. Sci Hortic 269:109317. https://doi.org/10.1016/j.scienta.2020.109317

Buler Z (2003) Effects of apple tree canopy on sunlight interception and distribution and yielding (in Polish). $\mathrm{PhD}$ thesis, Research Institute of Pomology and Floriculture, Skierniewice, Poland.

Caffagni A, Pecchioni N, Meriggi P, Bucci V, Sabatini E, Acciarri N, Ciriaci T, Pulcini N, Felicioni N, Beretta M, Milc J (2012) Iodine uptake and distribution in horticultural and fruit tree species. Ital J Agron 7:229-236. https://doi.org/ 10.4081/ija.2012.e32

Cakmak I, Prom-U-Thai C, Guilherme LRG, Rashid A, Hora KH, Yazici A, Savasli E, Kalayci M, Tutus Y, Phuphong $P$ et al (2017) Iodine biofortification of wheat, rice and maize through fertilizer strategy. Plant Soil 418:319-335. https://doi.org/10.1007/s11104-017-3295-9

Carini F, Bengtsson G (2001) Post-deposition transport of radionuclides in fruit. J Environ Radioact 52:215-236. https://doi.org/10.1016/S0265-931X(00)00034-5

Chao TT (1972) Selective dissolution of manganese oxides from soils and sediments with acidified $\mathrm{NH}_{2} \mathrm{OH} \cdot \mathrm{HCl}$. Soil Sci Soc Am Proc 36:764-768

Czynczyk A, Hodun G, Hodun M, Kruczyńska D (2004) Susceptibility of one-year-old shoots of scab-resistant apple cultivars to low temperatures in laboratory tests during four winters (1999/2000-2002/2003). Folia Hortic 16:61-72

Delange F (2000) The role of iodine in brain development. Proc Nutr Soc 59:75-79. https://doi.org/10.1017/S0029665100000094

Dillon JC, Milliez J (2000) Reproductive failure in women living in iodine deficient areas of West Africa. Br J Obstet Gynaecol 107:631-636. https://doi.org/10.1111/j.14710528.2000.tb13305.x

Eichert T, Fernandez V (2012) Uptake and release of elements by leaves and other aerial plant parts. In: Marschner P (ed) Marschner's mineral nutrition of higher plants. Academic Press, Oxford, UK, pp 71-84

Faust M, Shear CB (1972) Russeting of apples, an interpretive review. HortScience 7:233-235

Fuge R (1996) Geochemistry of iodine in relations to iodine deficiency disease. In: Appleton JD, Fuge R, Mccall GJH (eds) Environmental geochemistry and health. Geological Society Special Publication, London, pp 201-211

Fukui M, Fujikawa Y, Satta N (1996) Factors affecting interaction of radioiodide and iodate species with soil. J Environ Radioact 31:199-216. https://doi.org/10.1016/0265931X(95)00039-D

Gietka-Czernel M (2015) Iodine prophylaxis (in Polish). Post Nauk Med 12:839-845

Greenspan L (1977) Humidity fixed points of binary saturated aqueous solutions. J Res Natl Bur Stand Sect A81:89-96. https://doi.org/10.6028/jres.081a.011

Golob A, Novak T, Marsic NK, Sircelj H, Stibilj V, Jerse A, Kroflic A, Germ M (2020) Biofortification with selenium and iodine changes morphological properties of Brassica oleracea L. var. gongylodes and increases their contents in tubers. Plant Physiol Bioch. 150:234-243. https://doi.org/ 10.1016/j.plaphy.2020.02.044 
Gonzali S, Kiferle C, Perata P (2017) Iodine biofortification of crops: agronomic biofortification, metabolic engineering and iodine bioavailability. Curr Opin Biotechnol 44:1626. https://doi.org/10.1016/j.copbio.2016.10.004

Harker FR, Ferguson IB, Dromgoole FI (1988) Calcium ion transport through tissue discs of the cortical flesh of apple fruit. Physiol Plantarum 4:688-694

He FJ, MacGregor GA (2009) Comprehensive review on salt and health and current experience of worldwide salt reduction programs. J Hum Hypertens 23:363-384. https://doi. org/10.1038/jhh.2008.144

Hetzel BS (1983) Iodine deficiency disorders (IDD) and their eradication. Lancet 2:1126-1129

Hong CL, Weng HX, Qin YC, Yan AL, Xie LL (2008) Transfer of iodine from soil to vegetables by applying exogenous iodine. Agron Sustain Dev 28:575-583. https://doi.org/10. 1051/agro:2008033

Hong CL, Weng HX, Yan AL, Islam E (2009) The fate of exogenous iodine in pot soil cultivated with vegetables. Environ Geochem Health 31:99-108. https://doi.org/10. 1007/s10653-008-9169-

Hong CL, Weng HX, Jilani G, Yan A, Liu H, Xue Z (2012) Evaluation of iodide and iodate for adsorption-desorption characteristics and bioavailability in three types of soil. Biol Trace Elem Res. 146:262-271. https://doi.org/10. 1007/s12011-011-9231-6

Ittermann T, Albrecht D, Arohonka P, Bilek R, de Castro JJ, Dahl L, Nystrom HF, Gaberscek S, Garcia-Fuentes E, Gheorghiu ML, Hubalewska-Dydejczyk A, Hunziker S et al (2020) Standardized map of iodine status in Europe. Thyroid 9:1346-1354. https://doi.org/10.1089/thy.2019. 0353

Jackson JE (2003) Biology of apples and pears. Cambridge University Press, Cambridge, UK

Jin J, Martens DC, Zelazny LW (1987) Distribution and plant availability of soil boron fractions. Soil Sci Soc Am j 51:1228-1231

Johnson CC (1980) The geochemistry of iodine and a preliminary investigation into its potential use as a pathfinder element in geochemical exploration. $\mathrm{PhD}$ thesis, University College of Wales, Aberystwyth.

Johnson CC, Strutt MH, Hmeurras M, Mounir M (2002) Iodine in the environment of the High Atlas Mountain area of Morocco. British Geological Survey, Commissioned Report no. CR/02/196N, Keyworth, Nottingham, UK. Available from: https://www.researchgate.net/publication/ 264533017

Kabata-Pendias A, Pendias H (1999) Biogeochemistry of Trace Elements (in Polish). PWN, Warsaw, Poland

Kato S, Wachi T, Yoshihira K, Nakagawa T, Ishikawa A, Takagi D, Tezuka A, Yoshida H, Yoshida S, Sekimoto H, Takahashi M (2013) Rice (Oryza sativa L.) roots have iodate reduction activity in response to iodine. Fron Plant Sci. 4:227. https://doi.org/10.3389/fpls.2013.00227

Khanal BP, Grimm E, Finger S, Blume A, Knoche M (2013) Intracuticular wax fixes and restricts strain in leaf and fruit cuticles. New Phytol 200:134-143. https://doi.org/10. 1111/nph.12355

Kiferle C, Gonzali S, Holwerda HT, Ibaceta RR, Perata P (2013) Tomato fruits: a good target for iodine biofortification. Front Plant Sci. 4. https://doi.org/10. 3389/fpls.2013.00205

Kodama S, Takahashi Y, Okumura K, Uruga T (2006) Speciation of iodine in solid environmental samples by iodine K-edge XANES: application to soil and ferromanganese oxides. Sci Total Environ 363:275-284. https://doi.org/10. 1016/j.scitotenv.2006.01.004

Landini M, Gonzali S, Perata P (2011) Iodine biofortification in tomato. J Plant Nutr Soil Sci 174:480-486. https://doi. org/10.1002/jpln.201000395

Lawson PG, Daum D, Czauderna R, Meuser H, Härtling JW (2015) Soil versus foliar iodine fertilization as a biofortification strategy for field-grown vegetables. Front Plant Sci 6:450. https://doi.org/10.3389/fpls.2015.00450

Ledwozyw-Smolen I, Smolen S, Rozek S, Sady W, Strzetelski P (2020) Iodine biofortification of potato (Solanum tuberosum L.) grown in field. Agronomy 10, 1916. https:// doi.org/10.3390/agronomy 10121916

Mao H, Wang J, Wang Z, Zan Y, Lyons G, Zou C (2014) Using agronomic biofortification to boost zinc, selenium, and iodine concentrations of food crops grown on the loess plateau in China. J Soil Sci Plant Nutr 14:459-470

Medrano-Macias J, Leija-Martinez P, Gonzalez-Morales S, Juarez-Maldonado A, Benavides-Mendoza A (2016) Use of iodine to biofortify and promote growth and stress tolerance I crops. Front Plant Sci 7:1-20. https://doi.org/10. 3389/fpls.2016.01146

Mercik S (2004) Theoretical and practical aspects of fertilization (in Polish). SGGW, Warsaw, Poland.

Mika A, Buler Z (2015) Modifying apple spindle trees to improve fruit quality. Acta Sci Pol Hortorum Cultus 14:13-24

Muramatsu Y, Christoffers D, Ohmomo Y (1983) Influence of chemical forms on iodine uptake by plant. J Radiat Res 24:326-338. https://doi.org/10.1269/jrr.24.326

Nosecka B, Zaremba $Ł$ (2019) Rynek owoców w UE in Polsce. Rynek Owoców i Warzyw 2:6-22

Nowosielski O (1988) The rules of fertilization in horticultural crops (in Polish). PWRiL, Warsaw, Poland.

Oestling O, Kopp P, Burkart W (1989) Foliar uptake of cesium, iodine and strontium and their transfer to edible parts of beans, potatoes and radishes. Radiat Phys Chem 33:551-554

Ostrowska A, Gawliński S, Szczubiałka Z (1991) Analysis of soils and plants (in Polish). IOŚ, Warsaw, Poland.

PN-EN 15111 (2008) Food stuffs - determination of trace elements - determination of iodine by ICP-MS (inductively coupled plasma mass spectrometry). Polish Committee for Standardization, Warsaw (in Polish).

Rosen CJ, Bierman PM, Telias A, Hoover EE (2006) Foliarand fruit-applied strontium as a tracer for calcium trasport in apple trees. HortScience 41:220-224

Schmitz K, Aumann DC (1994) Why are the soil-to-pasture transfer factors, as determined by field-measurements for I-127 lower than for I-129. J Environ Radioact 24:91-100. https://doi.org/10.1016/0265-931X(94)90027-2

Schnell D, Aumann DC (1999) The origin of iodine in soil: II. Iodine in soils of Germany. Chem Erde-Geochem 59:69-76 
Shetaya WH, Young SD, Watts MJ, Ander EL, Bailet EH (2012) Iodine dynamics in soil. Geochim Cosmochim Acta 77:457-473. https://doi.org/10.1016/j.gca.2011.10.034

Shönherr J (2001) Cuticular penetration of calcium salts: effects of humidity, anions, and adjuvants. J Plant Nutr Soc Sci 164:225-231. https://doi.org/10.1002/15222624(200104) 164:2\% 3c225::AID-JPLN225\%3e3.0. $\mathrm{CO} ; 2-\mathrm{N}$

Smolen S, Kowalska I, Sady W (2014) Assessment of biofortification with iodine and selenium of lettuce cultivated in the NFT hydroponic system. Sci Hort 166:9-16. https:// doi.org/10.1016/j.scienta.2013.11.011

Smolen S, Rozek S, Strzetelski P, Ledwozyw-Smolen I (2011) Preliminary evaluation of the influence of soil fertilization and foliar nutrition with iodine on the effectiveness of iodine biofortification and mineral composition of carrot. J Elementol 6:103-113

Sobiczewski P, Łabanowska B, Bryk H, Sekrecka M, Lisek J (2018) Programs of protection of fruit crops (in Polish). Hortpress, Warsaw, Poland.

Strazzullo P, D'Elia L, Kandala NB (2009) Salt intake, stroke, and cardiovascular disease: meta-analysis of prospective studies. Brit Med j 339:45-67. https://doi.org/10.1136/ bmj.b4567

Szczepański K, Rejman S (1987) Statistical analysis in pomology (in Polish). PWRiL, Warsaw, Poland.

Świetlik D, Faust M (1984) Foliar nutrition of fruit crops. Hortic Rev 6:287-355. https://doi.org/10.1002/9781118060797.ch8

Trofimiuk-Müldner M, Konopka J, Sokołowski G, Dubiel A, Kieć-Klimczak M, Kluczyński Ł, Motyka M, Rzepka E, Walczak J, Sokołowska M, Buziak-Bereza M et al (2020) Current iodine nutrition status in Poland (2017): is the Polish model of obligatory iodine prophylaxis able to eliminate iodine deficiency in the population? Public Health Nutr 14:2467-2477. https://doi.org/10.1017/S1368980020000403

Um W, Serne RJ, Krupka KM (2004) Linearity and reversibility of iodide adsorption on sediments from Hanford, Washington under water saturated conditions. Water Res 38:2009-2016. https://doi.org/10.1016/j.watres.2004.01. 026

Van Goor BJ (1973) Penetration of surface-applied ${ }^{45} \mathrm{Ca}$ into apple fruit. J Hort Sci 48:261-270

Watts MJ, Mitchell CJ (2009) A pilot study on iodine in soils of Greater Kabul and Nangarhar provinces of Afghanistan. Environ Geochem Health 4:503-509. https://doi.org/10.1007/ s10653-008-9202-9

Weng H, Hong CL, Xia TH, Bao LT, Liu HP, Li DW (2013) Iodine biofortification of vegetable plants - an innovative method for iodine supplementation. Chinese Sci Bull 58:2066-2072. https://doi.org/10.1007/ s11434-013-5709-2
Weng HX, Weng JK, Yan AL, Yong HCL, WB, Qin YC, (2008) Increment of iodine content in vegetable plants by applying iodized fertilizer and the residual characteristics of iodine in soil. Biol Trace Elem Res 123:218-228

Weng H, Yan A, Hong C, Qin YC, Pan L, Xie L (2009) Biogeochemical transfer and dynamics of iodine in a soil-plant system. Environ Geochem Health 31:401-411. https://doi. org/10.1007/s10653-008-9193-6

White PJ, Broadley MR (2009) Biofortification of crops with seven mineral elements often lacking in human diets iron, zinc, copper, calcium, magnesium, selenium and iodine. New Phytol 182:49-84. https://doi.org/10.1111/j. 1469-8137.2008.02738.x

Whitehead DC (1984) The distribution and transformations of iodine in the environment. Environ Int 10:321-339

Winger RJ, König J, House DA (2008) Technological issues associated with iodine fortification of foods. Trends Food Sci Technol 19:94-101. https://doi.org/10.1016/j.tifs. 2007.08.002

World Health Organization (2007) Assessment of the iodine deficiency disorders and monitoring their elimination. A guide for programme managers, 3rd edn. WHO Press, Geneva, Switzerland.

World Health Organization (2014) Guideline: fortification of food-grade salt with iodine for the prevention and control of iodine deficiency disorders. WHO Press, Geneva, Switzerland. https://apps.who.int/iris/handle/10665/136908

Wójcik P (1999) Boron fertilization and nutrition of apple trees (in Polish). PhD thesis, Research Institute of Pomology and Floriculture, Skierniewice, Poland.

Wójcik P (2001) 'Jonagold' apple fruit quality as influenced by fall sprays with calcium chloride at high rates. J Plant Nutr 24:1925-1936. https://doi.org/10.1081/PLN-100107604

Wójcik P (2009) Fertilizers and fertilization of fruit trees (in Polish). Hortpress, Warsaw, Poland

Wójcik P, Gubbuk H, Akgül H, Gunes E, Ucgun K, Koçal H, Küçükyumuk C (2009) Effect of autumn calcium spray at a high rate on 'Granny Smith' apple quality and storability. J Plant Nutr 33:46-56. https://doi.org/10.1080/ 01904160903391073

Wójcik P, Skorupińska A, Filipczak J (2014) Impacts of preharvest fall sprays of calcium chloride at high rates on quality and 'Conference' pear storability. Sci Hortic 168:51-57. https://doi.org/10.1016/j.scienta.2014.01.017

Zimmerman MB, Jooste PL, Pandav CS (2008) Iodine-deficiency disorders. Lancet 372:1251-1262. https://doi.org/10.1016/ S0140-6736(08)61005-3

Publisher's Note Springer Nature remains neutral with regard to jurisdictional claims in published maps and institutional affiliations. 